Zhou, K.; Remy, C.; Kabbe, C.; Barjenbuch, M.

\title{
Comparative environmental life cycle assessment of phosphorus recovery with different generations of the AirPrex $\mathbb{R}$ systems
}

Journal article | Accepted manuscript (Postprint)

This version is available at https://doi.org/10.14279/depositonce-8128

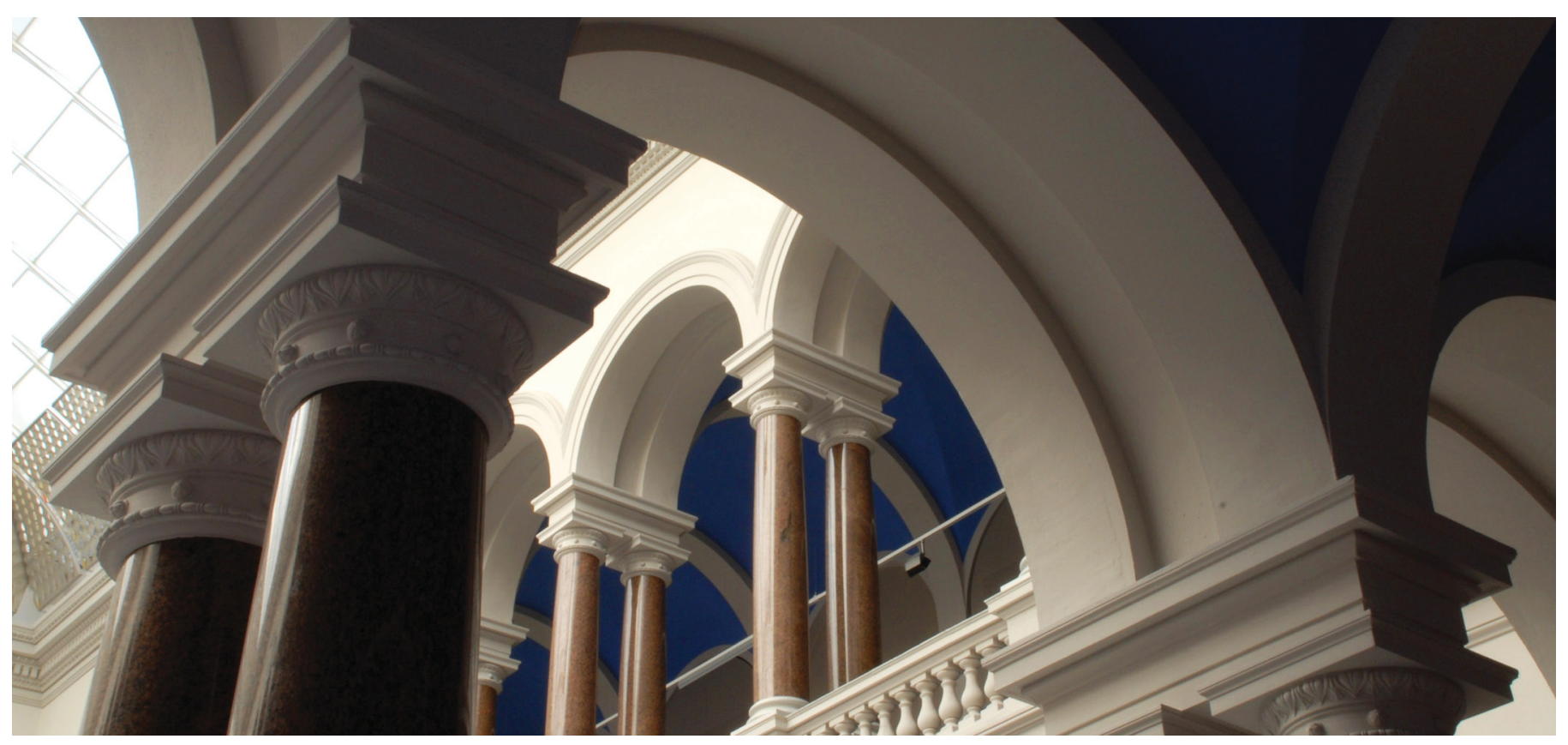

Zhou, K., Remy, C., Kabbe, C., \& Barjenbruch, M. (2018). Comparative environmental life cycle assessment of phosphorus recovery with different generations of the AirPrex $®$ systems. International Journal of Environmental Science and Technology.

https://doi.org/10.1007/s13762-018-1881-x

This is a post-peer-review, pre-copyedit version of an article published in the International Journal of Environmental Science and Technology. The final authenticated version is available online at:

http://dx.doi.org/10.1007/s13762-018-1881-x 
Comparative Environmental Life Cycle Assessment of phosphorus recovery with different generations of the AirPrex ${ }^{\circledR}$ systems

Running title:

Life Cycle Assessment of phosphorus recovery with AirPrex ${ }^{\circledR}$ process

Graphical abstract

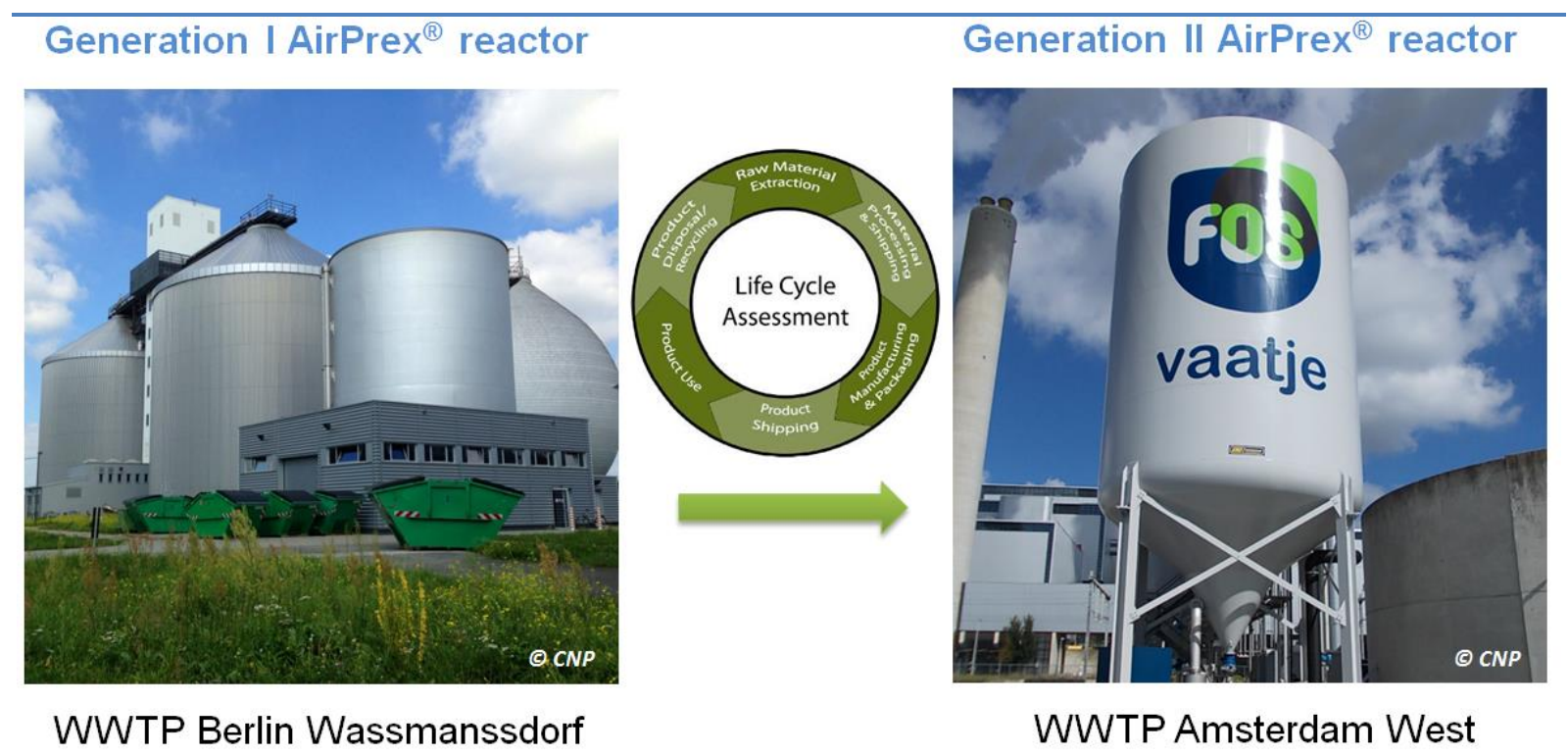

Highlights:

- P mass balance for both WWTPs with P-recovery was given

- Comparison of two different AirPrex ${ }^{\circledR}$ reactor systems was conducted

- LCA process data were taken from the full-scale phosphorus recovery plant

- Cumulative fossil energy demand was calculated

- Environmental impact (Climate change, Eutrophication) was assessed 


\section{Abstract:}

Phosphorus (P) recovery through struvite is already both technically and economically feasible. This has been proved by more than 40 large-scale plants worldwide. However, when designing and implement these P-recovery technologies, the environmental effects need to be considered. Therefore, a comparative environmental life cycle assessment of phosphorus recovery with different generations of the AirPrex ${ }^{\circledR}$ reactors at WWTP Wassmannsdorf and Amsterdam West was carried out in this study. Results show that both AirPrex ${ }^{\circledR}$ configurations with 1-reactor and 3-reactor have positive energy benefits and better environmental credits for the Global Warming Potential (GWP), Freshwater Eutrophication Potential (FEP), and Marine Eutrophication Potential (MEP). The 3-reactor configuration shows better results in cumulative energy demand with 35\% improvement of energy surplus, $36 \%$ reduction of Global Warming Potential (GWP) and less eutrophication potential. These improvements are mainly due to optimized struvite precipitation and harvesting, and show that technology can be developed further, especially in plant operation and not only in the laboratory or pilot plant.

Keywords:

Climate change; Energy demand; Environmental impact; Eutrophication; Phosphorus recovery; Struvite 


\section{Introduction}

Phosphorus (P) is an essential but limited resource (Asimov, 1959). In recent years, technologies for phosphorus recovery have been developed further and some of them have been implemented on a large scale, making municipal wastewater and sludge promising secondary phosphorus sources. P-recovery through struvite is already both technically and economically feasible (Zhou et al., 2017, Amann et al., 2018, Peng et al., 2018). This has been proved by more than 50 large-scale plants worldwide. There are approx. 10,000 tones/a of struvite currently produced in Europe are likely to double in the coming five years (Kabbe and Kraus, 2017, Egle et al., 2015). However, when designing and implement these P-recovery technologies, the environmental effects need to be considered. The AirPrex ${ }^{\circledR}$ technology is one of the promising technologies for phosphorus recovery from sludge liquid of digested sludge with 8 full-scale plants. Therefore, a Life Cycle Assessment (LCA) is carried out in order to compare the environmental impact of phosphorus recovery with the one-reactor AirPrex ${ }^{\circledR}$ configuration at WWTP Berlin Wassmannsdorf and the three-reactor AirPrex ${ }^{\circledR}$ configuration at WWTP Amsterdam West. The full-scale operational data in both plants e.g. demand for electricity, chemicals, product yield and side effects were used to accomplish the assessment. The cumulative energy demand and related environmental impacts (e.g. greenhouse gas emissions, freshwater eutrophication potential, marine eutrophication potential) were selected as environmental indicators for the LCA. The data collection, modelling and environmental impact assessment for this study was conducted in Berlin Centre of Competence for Water and Technische Universität Berlin from September 2015 to September 2017.

\section{Phosphorus recovery with AirPrex ${ }^{\circledR}$ Process}

The AirPrex ${ }^{\circledR}$ technology was first developed by the "Berliner Wasserbetriebe (BWB)" after being affected by massive incrustations at their plant. The incrustations found in the centrifuges of WWTPs were later proved to consist mainly of struvite with small portions of different calcium phosphate compounds (Heinzmann and Engel, 2006). The advantages of the AirPrex ${ }^{\circledR}$ process are not only P-recovery, but also economic benefits for the WWTP operation. About $70 \%$ of the economic benefits of the AirPrex ${ }^{\circledR}$ process come from reduction of the handling costs of biosolids and polymers costs. About $20 \%$ of the savings are due to lower maintenance requirments associated with struvite and $10 \%$ is the potential revenue from fertilizer sales (Rulseh, 2015). 
In the AirPrex ${ }^{\circledR}$ process, the digested sludge is led through a so-called "airlift reactor", in which air is used to create internal recycle flows (Figure S1). The aeration has two functions. First, it increases the $\mathrm{pH}$ value from 7 to 8 by stripping $\mathrm{CO}_{2}$ from the digested sludge. Second, it creates a loop convection within the reactor by central air injection and the baffles is to initiate inner upflow and outer downflow of sludge. The airlift reactor sets the retention time of the growing struvite crystals, which sink to the bottom when reaching a certain size. Ammonium ions $\left(\mathrm{NH}_{4}{ }^{+}\right)$and phosphate ions $\left(\mathrm{PO}_{4}{ }^{3-}\right)$ are present in sufficient concentrations in the digested sludge. By adding magnesium ions $\left(\mathrm{Mg}^{2+)}\right.$, usually as magnesium chloride $\left(\mathrm{MgCl}_{2}\right)$, to the reactor, struvite $\left(\mathrm{NH}_{4} \mathrm{MgPO}_{4} \cdot 6 \mathrm{H}_{2} \mathrm{O}\right)$ is formed. The formed Struvite crystals are suspended in the sludge until they reached a limited size, where their sink rate faster than the circulation rate. Struvite has a density of $1.7 \mathrm{~g} / \mathrm{cm}^{3}$ and therefore can be collected at the bottom of the reactor. It is then separated from organic residues by a sand washer. Afterwards, the crystals are atmospherically dried and the product is brought to the market or user.

At the moment, eight full-scale plants are in operation. In these plants $80-90 \%$ of the phosphate is removed from the liquid phase of the digested sludge as struvite (CNP, 2017). Table $\mathrm{S} 1$ gives an overview of the current operational plants.

The first installation of AirPrex ${ }^{\circledR}$ at WWTP Wassmannsdorf (WMD) in Berlin and the largest AirPrex ${ }^{\circledR}$ plant at WWTP Amsterdam West (AMS) were chosen for comparison in this study. The AirPrex ${ }^{\circledR}$ system in Berlin has only one big reactor, while in Amsterdam there are three separated reactors. The AirPrex ${ }^{\circledR}$ system in Amsterdam has higher struvite yield, but with higher energy demand and more materials used for the infrastructure compared to Wassmannsdorf. The objective of this study is to compare the environmental impact of the two AirPrex ${ }^{\circledR}$ reactor systems. The ultimate goal of this study is to develop an analysis that could assist decision-makers in considering environmental effects when designing new AirPrex ${ }^{\circledR}$ processes in different treatment plants.

\section{Phosphorus mass balance and AirPrex ${ }^{\circledR}$ reactor in WWTP Amsterdam West and Wassmannsdorf}

\subsection{AirPrex ${ }^{\circledR}$ process in WWTP Wassmannsdorf}

WWTP Wassmannsdorf currently has a daily treatment capacity of $180,000 \mathrm{~m}^{3}$ of wastewater daily during dry weather. The sludge treatment lines include three centrifuges for excess sludge thickening, six digesters each with a volume of $8,000 \mathrm{~m}^{3}$ and five centrifuges for sludge dewatering (BWB, 2017b). 
Figure 1 shows the process scheme and P balance of WWTP Wassmannsdorf. About 96.7\% of total phosphate was eliminated from wastewater to sludge. In the AirPrex ${ }^{\circledR}$ reactor, $87 \%$ of the orthophosphate was removed from the sludge liquid phase, but the real $\mathrm{P}$ harvesting in struvite was only about $14 \%$ with regards to the dissolved orthophosphate in the sludge. About $74 \%$ of the produced struvite was still contained in the dewatered sludge. This part of struvite and the residual phosphorus were incinerated. In Wassamnsdorf, a part of the dewatered sludge (16\% of DM) is transported to the mono-incineration plant in BerlinRuhleben, while the rest ( $50 \%$ of DM) is transported to different lignite power plants for coincineration (Remy, 2012). In order to utilize the thermal energy of sludge completely and recover more phosphorus in accordance with the new sewage sludge ordinance, the BWB will start the construction of a mono-incineration plant in 2022 (BWB, 2017a)

To solve the operational problem of struvite crystallization in pipes and pumps, the BWB built the first AirPrex ${ }^{\circledR}$ reactor (Figure S2) in 2009 which was put in operation in March 2010. The AirPrex ${ }^{\circledR}$ process in Berlin is a one reactor system with a volume of $800 \mathrm{~m}^{3}$. Using air stripping (2000-3000 $\left.\mathrm{m}^{3} / \mathrm{h}\right)$, the $\mathrm{CO}_{2}$ in the sludge is stripped and the $\mathrm{pH}$ value in the rector increases from 7.2 to 7.8-8 (Heinzmann and Lengemann, 2011, Kern et al., 2008). After adding 5.3 L 30\% magnesium chloride solution per cubic meter sludge ( $\mathrm{Mg}: \mathrm{P}$ molar ratio=1.7), the dissolved orthophosphate concentration in the sludge water decreases by $87 \%$, on average from $387 \mathrm{mg} / \mathrm{l}$ to $49 \mathrm{mg} / \mathrm{l}$ in 2016 (Lengemann, 2017). The sludge retention time in the reactor is about 10.5 hours. The energy demand for the AirPrex ${ }^{\circledR}$ system is $2.2 \mathrm{kWh} / \mathrm{m}^{3}$ sludge.

\subsection{AirPrex $^{\circledR}$ process in WWTP Amsterdam West}

WWTP Amsterdam West is one of the largest WWTP of WATERNET in the Netherlands. It was opened in 2005 and has a treatment capacity of 168,000 $\mathrm{m}^{3} / \mathrm{d}$ of dry weather influent. At the WWTP Amsterdam West (in total 1 million people equivalent), using enhanced biological phosphorus removal, massive scaling problems occurred after digestion of the primary and secondary sludge. In order to solve the operational problems, the AirPrex ${ }^{\circledR}$ process was implemented in 2014, and the WWTP Amsterdam West has become one of Europe's largest production facilities of struvite. Figure 2 shows the process scheme and P balance at WWTP Amsterdam West.

The WWTP Amsterdam West does not only process the sludge from its own treatment (approx. $91 \mathrm{t} \mathrm{DS/d),} \mathrm{but} \mathrm{also} \mathrm{that} \mathrm{of} \mathrm{the} \mathrm{nearby} \mathrm{WWTP} \mathrm{Westpoort} \mathrm{and} \mathrm{that} \mathrm{of} \mathrm{some} \mathrm{other}$ 
external sources (approx. $13 \mathrm{t} \mathrm{DS/d).} \mathrm{The} \mathrm{external} \mathrm{sludge} \mathrm{is} \mathrm{collected} \mathrm{in} \mathrm{the} \mathrm{Central} \mathrm{Sludge}$ Intake. The primary sludge is thickened by gravity thickeners and the secondary sludge by belt thickeners. After that, all sludge is treated in anaerobic digesters, where the sludge is stabilized, its volume is reduced and biogas is produced. At last, the sludge is dewatered in bowl centrifuges, after which it is transported for incineration in a waste incineration plant (Bergmans, 2011, Veltman, 2016).

The AirPrex ${ }^{\circledR}$ process at WWTP Amsterdam West was launched in Dezember 2013. As shown in Figure S3, the AirPrex ${ }^{\circledR}$ system includes three reactors. The first a volume of $500 \mathrm{~m}^{3}$ and the second reactor a volume of $250 \mathrm{~m}^{3}$ are with air stripping and magnesium chloride dosing. In total $1000 \mathrm{Nm}^{3} / \mathrm{h}$ of air are dosed in the first two reactors. The total residence time of sludge is between 8 to 10 hours depending on the sludge flow. The third reactor is used only for struvite settling with a volume of $250 \mathrm{~m}^{3}$. Two magnesium chloride storage tanks have a volume of $50 \mathrm{~m}^{3}$ each. With the three reactor systems, the harvesting efficiency of struvite can achieve $21 \%$ with regards to the dissolved ortho-P in the digester sludge.

\subsection{Comparison of Airprex ${ }^{\circledR}$ system in WWTP Wassmannsdorf and}

\section{Amsterdam West}

The difference between the AirPrex ${ }^{\circledR}$ system in WWTP Wassmannsdorf (WMD) and in WWTP Amsterdam West (AMS) is described in Table 1. WWTP AMS has a higher harvesting efficiency of struvite due to the reactor design. The three separate reactor systems have a lower sludge retention time, but achieve a better separation of crystals from sludge due to a better crystallization condition in the first two reactors and an additional idle phase for struvite precipitation in the third reactor. The WMD reactor $\left(33 \mathrm{Nm}^{3}\right.$ air $/ \mathrm{m}^{3}$ sludge $)$ has more than twice the amount of air pumped into the sludge than in AMS $\left(15 \mathrm{Nm}^{3} / \mathrm{m}^{3}\right)$, but the energy demand of WMD is lower than in AMS. This is mainly due to the sludge transport between three reactors system. Data of operational benefits show that the AirPrex ${ }^{\circledR}$ reactor installed in AMS is more efficient than the one in Berlin. AMS achieved a higher sludge dewatering improvement and polymer saving after using the AirPrex ${ }^{\circledR}$ system. By aeration and $\mathrm{pH}$ increase, the ammonia gas is stripped with $\mathrm{CO}_{2}$ from liquid phase to gas phase. The AirPrex ${ }^{\circledR}$ reactor in WMD is uncovered and emits ammonia directly into the air, while the aeration reactor in AMS is closed and the exhaust gas is treated in a biofilter. However, it is to be considered that, the AirPrex ${ }^{\circledR}$ system in AMS has a higher demand for energy, magnesium chloride doses and infrastructure. For a more accurate comparison of the environmental 
impacts of the both reactors, Life Cycle Assessment (LCA) was used to evaluate the cumulative energy demand, the Greenhouse Gas emission and Eutrophication potential.

A total of EUR 2.3 million was invested for the one reactor AirPrex ${ }^{\circledR}$ system in WMD (Egle, 2014) while in AMS EUR 3 million was invested for the three reactor AirPrex ${ }^{\circledR}$ system (Veltman, 2016). It is estimated that in AMS the savings of installation of AirPrex ${ }^{\circledR}$ reactor is EUR 500,000 per year, (from that total benefits of EUR 1.2 million per year and operational costs of EUR 700,000 per year) with return on investment (ROI) of 6 years. In WMD the annual saving is between EUR 250,000 to 300,000 per year.

\section{Methodology and system details}

\subsection{Methodology of Life Cycle Assessment}

Life Cycle Assessment is an internationally standardized method for the evaluation of the environmental burdens and resources consumed along the life cycle of products or processes (ISO-14040, 2006, ISO-14044, 2006). For assessing technical processes and systems in their potential environmental impacts, the method of Life Cycle Assessment (LCA) has been developed and applied widely within research and industry (Grahl, 2009), also in the field of wastewater and sludge treatment (Wenzel et al., 2008, Corominas et al., 2013, Remy et al., 2012).

Typical environmental effects that can be assessed using LCA include eutrophication, global warming, human health, and air acidification. LCA can be used to analyze the differences in environmental effect between multiple processes that accomplish the same task or function.

Umberto $^{\circledR}$ NXT LCA is a software package providing a graphical interface for life cycle assessment. Umberto ${ }^{\circledR}$ NXT LCA is licensed and maintained by ifu Hamburg GmbH (Institut für Umweltinformatik). Umberto ${ }^{\circledR}$ NXT LCA supports environmental consultants, process engineers, and process technicians in developing comprehensive analyses of product life cycles.

Ecoinvent is a commercial database set for life cycle assessment of the Ecoinvent Association, which was originally known as the Ecoinvent Centre, the Swiss Centre for Life Cycle Inventories. The Ecoinvent database is one of the market leaders in this field. The Ecoinvent version 3 is the latest database of the provider. It contains more than 11,500 data sets and offers a lot of new and updated data sets (IFU, 2017). 


\subsection{Goal and scope definition}

The purpose of this study is to quantify the life cycle environmental impacts of different reactor systems for the AirPrex ${ }^{\circledR}$ process. The assessment is based on a reference system, which is defined as the sludge line treating the mixed sludge of WWTP Wassmannsdorf. The following relevant side effects on the sludge treatment or the mainstream WWTP are considered:

- Demand of electricity, chemicals

- Product yield (t/a P) and quality

- Substitution of mineral fertilizer production (only $\mathrm{P}$ and $\mathrm{N}$ accounted)

- Side effects (return load, dewatering)

The function unit is chosen as sludge treatment and disposal of annual load in WMD (39127 t TS/a). The sludge treatment line can represent the view from the WWTP operator for the effect of sludge treatment. An alternative F.U. is chosen as $1 \mathrm{~kg}$ P product. This P-fertilizer perspective (1 $\mathrm{kg} \mathrm{P}$ ) gives information about the environmental impact of one $\mathrm{kg}$ recovered $\mathrm{P}$.

The ultimate goal of this study is to develop an analysis that could assist decision-makers (engineers, owners, regulators, etc.) in considering environment effects when optimizing or designing new AirPrex ${ }^{\circledR}$ processes in the treatment plants.

\subsection{System boundary and scope definition}

The reference system consists of the WWTP Wassmannsdorf sewage sludge line with data based on previous work of EU research project P-REX. The boundaries include all relevant treatment steps for sewage sludge, beginning with raw sludge consisting of a mixed sewage sludge, digestion, heat and power production from biogas in a combined heat and power plant (CHP), dewatering with a decanter, transport of dewatered sludge to the mono-incineration plant, sludge mono-incineration and ash disposal. Also included as background processes are the production of fuels, chemicals, electricity and additional infrastructure demand of the two scenarios. Figure 3 shows the boundaries of this LCA study. Inventories from the Ecoinvent database are accounted as European data sets.

A reference system without the AirPrex ${ }^{\circledR}$ reactor is prepared to compare two different scenarios. To reduce the impact factors of different infrastructure (i.e. sludge composition, disposal route, etc.), it is assumed that, Berlin Wassmannsdorf builds a new AirPrex ${ }^{\circledR}$ system as in Amsterdam for comparison in Scenario 2.

Two scenarios and a reference system as a baseline are modelled in this LCA for comparison:

- Reference Scenario: Sludge treatment and disposal at WMD 
- Scenario 1: P-recovery with 1-reactor configuration at WMD

- Scenario 2: P-recovery with 3-reactor configuration at WMD

\section{Reference input flows:}

The reference input sludge flow is shown in Table S2 and defined as the mixed sludge in Wassmannsdorf, which enter the system of sludge handling. The quantity and quality of the mixed sludge in WWTP Wassmannsdorf are given or measured by the BWB staff in 2016.

\section{Indicators of Life Cycle Impact Assessment:}

There are different areas of protection declared in ISO 14044, but according to the goal of the LCA study only cumulative energy demand and the natural environment are considered. For the environmental impacts assessed in this study, the following indicators are relevant:

- Cumulative energy demand of fossil and nuclear origin (VDI, 2012)

- Global warming potential: $\mathrm{CO}_{2}$ footprint including fossil $\mathrm{CO}_{2}, \mathrm{~N}_{2} \mathrm{O}, \mathrm{CH}_{4}$

- Fresh Water Eutrophication Potential (FEP): P emissions into water and soil

- Marine Eutrophication Potential (MEP): $\mathrm{N}$ emissions into air, water and soil (Goedkoop et al., 2009)

\section{Data Quality:}

It is clear that different quality of input data results in different reliability of the output results. To collect AirPrex ${ }^{\circledR}$ operational data (energy demand, chemical demand etc.), questionnaires were sent to operators and were iteratively checked with literature and expert opinions.

The sludge input data was from Wassmannsdorf with average monthly measurements in 2016 (Lengemann, 2017). The data for the demand of electricity, heat and chemicals of each process was taken from the project CoDiGreen (Remy, 2012) with the operational data in 2009. Data of AirPrex ${ }^{\circledR}$ reactor (efficiency, struvite production, energy demand etc.) for the process model was collected from the process engineers of the WWTP Wassmannsdorf and WWTP Amsterdam West with questionnaires or emails. The data the of mono-incineration plant is based on the project P-REX (Remy et al., 2015) from the project partner Outotec.

\section{Limitations:}

- The direct comparison of the AirPrex ${ }^{\circledR}$ process in two WWTPs is difficult due to the influence of the WWTP itself and different sludge disposal routes

- The data of input sludge, treatment process and AiPrex ${ }^{\circledR}$ reactor is from different years 
- The sludge dry matter improvement has different initial dry matter values, i.e. in WWTP Wassmannsdorf from 25\% to $27 \%$ and in WWTP Amsterdam West from 21\% to $23.5 \%$

- The polymer savings also have a different initial demand, i.e. in WWTP

Wassmannsdorf from 12 to $9 \mathrm{~g} / \mathrm{kg}$ TSS and in WWTP Amsterdam West from 17 to 13 $\mathrm{g} / \mathrm{kg}$ TSS

\subsection{Life Cycle Inventory}

The existing process of sludge handling and disposal at WWTP Berlin Waßmanndorf includes stabilization by anaerobic digestion, dewatering and drying, and incineration of stabilized sludge. This chapter summarizes all relevant data used for the process model of this LCA (“Life Cycle Inventory”). The process model is set up using the LCA software UMBERTO ${ }^{\circledR}$. Figure S4 shows the reference system used for the Life Cycle Inventory Analysis (LCI). The LCI is carried out by using version 7.1 of Umberto NXT LCA by ifu Hamburg GmbH. The reference system is sub-divided into functional system units.

\section{- Digester and CHP unit}

The digester unit used in the system (Table S3) represents the mesophilic digester at WWTP Wassmannsdorf. The volatile suspended solid (VSS) degradation is estimated empirically to $47 \%$, while the biogas yield is $423 \mathrm{NL} / \mathrm{kg} \mathrm{V} \mathrm{SS}$ In and the methane content of the biogas is $60.5 \%$. The electricity demand of the digester is $4.1 \mathrm{kWh} / \mathrm{m}^{3}$ Sludge, consisting of required energy for mixing and sludge pumping. The sludge is also preheated using $20 \mathrm{kWh} / \mathrm{m}^{3}$ of thermal energy before it is fed to the digesters.

\section{- $\operatorname{AirPrex}^{\circledR}$ process}

Digested sludge is pumped to the AirPrex ${ }^{\circledR}$ reactor (Scenario 1 and 2). The differences of the operational data are shown in Table S4. The harvesting efficiency of AirPrex ${ }^{\circledR}$ process describes the relation of the amount of total $\mathrm{P}$ that is recovered in the product and the contained dissolved ortho-P in digested sludge. With the three-reactor system in Amsterdam, there is a higher demand for electricity needed for pumping sludge to the different reactors.

\section{- Dewatering Unit}

In the sludge after digestion the TS of digested sludge decreased from 5.9 to $3.4 \%$. With the AirPrex ${ }^{\circledR}$ system the TS content of dewatered sludge was improved from $25 \%$ to $27 \%$ in Scenario 1, while in Scenario 2 has a higher improvement to $27.5 \%$ due to a lower $\mathrm{PO}_{4}-\mathrm{P}$ content in the sludge water (Table S5). With lower dissolved Ortho-P concentration in sludge liquid, higher TS can be achieved by dewatering (Forstner, 2015). 
The polymer demand is decreased from 12 to $9 \mathrm{~g} / \mathrm{kg}$ TSS with the AirPrex ${ }^{\circledR}$ system. In scenario 2 , the polymer demand is lower than in scenario 1 with $8 \mathrm{~g} / \mathrm{kg}$ TSS. The energy demand for both scenarios is the same with $3.8 \mathrm{kWh} / \mathrm{m}^{3}$ sludge.

\section{- Return load and smplified WWTP}

Within the boundaries of the reference system, there is a simplified WWTP model for treatment of the return load after the dewatering unit. Calculations are mainly based on the modelling by KWB within the research project CoDiGreen and P-REX.

In the simplified WWTP (Table S6), aeration efficiency is stated as $0.5 \mathrm{kWh} / \mathrm{kg} \mathrm{O} \mathrm{O}_{2}$ and removal goals for $\mathrm{COD}, \mathrm{NH}_{4}-\mathrm{N}, \mathrm{TN}$ and $\mathrm{TP}$ are respectively estimated at $90 \%, 99 \%$ (full nitrification), 80\% (denitrification) and 96\% (P-removal).

The data of the return load is taken from the operational data in 2016 (Table S7). The AirPrex ${ }^{\circledR}$ reactor reduced $85 \%$ orthophosphate in centrat in Scenario 1 and $95 \%$ in Scenario 2. About $12-13 \%$ of ammonium nitrogen in sludge liquid is precipitated in struvite.

\section{- Mono-Incineration Plant}

In Wassmannsdorf, the sludge is incinerated in mono-incineration plant, different lignite power plants and cement kilns. WWTP Wassmannsdorf will build a mono-incineration plant nearby in 2022 (BWB, 2017b). For simplification, the dewatered sludge will be calculated for the mono-incineration plant with a transport distance of $5 \mathrm{~km}$. For the LCA, a state of the art mono-incineration plant, based on data from the engineering company Outotec for the Zurich incinerator is modelled (Remy et al., 2015). The operational data is shown in Table S8. The thermal energy is recovered and injected in district heating, while electrical energy is produced in steam turbine.

\section{- Disposal of Ash}

Ashes from mono-incineration $(0.2 \mathrm{~kg} / \mathrm{kg}$ TS) are transported to landfills $(100 \mathrm{~km})$ (Jossa, 2014, Remy et al., 2015). Disposal of mono-incinerated sewage sludge ash is modelled via a data set market for hazardous waste, for underground deposit according to Econinvent database version 3.0.2.1. The data set includes all upstream activities from cradle to grave. The used data set refers to average global data in the years 2011-2013.

\section{- Phosphorus and nitrogen fertilizer production}

Phosphorus fertilizer production and nitrogen fertilizer production are modelled via a data set market for phosphate and nitrogen fertilizer (Jossa, 2014, Remy et al., 2015), as $\mathrm{P}_{2} \mathrm{O}_{5}$ and $\mathrm{N}$ of econinvent database version 3.0.2.1. The data set includes all upstream activities from cradle to grave. The used data set refers to average global data in the years 2011-2013. 


\section{Life Cycle Impact Assessment and results}

\section{- Cumulative Energy Demand (CED)}

The difference between reference scenarios and AirPrex ${ }^{\circledR}$ scenarios in energy demand per year (including fossil and nuclear) is displayed in Figure 4. Compared to the reference system, additional electricity for the AirPrex ${ }^{\circledR}$ reactor (approx. 16 million MJ) and for the magnesium chloride production (approx. 8 million MJ) is needed. The negative impact is equivalent to an energetic surplus of sludge treatment and disposal compared to the reference system. The main energy savings are savings from polymer (approx. 8 million MJ), higher electricity production in mono-incineration (approx. 14 million MJ) and heat for district heating to substitute natural gas (approx. 20 million MJ). The polymer savings and improvements in dewaterability of digested sludge enable a better energy recovery in mono-incineration and therefore obtain the saving of energy credits. Without sludge disposal, avoided production of mineral fertilizer alone cannot cover the additional efforts in energy and chemical demand.

Compared to Scenario 1 with 1-reactor configuration, Scenario 2 with 3-reactor configuration has a higher electricity demand, but also a higher benefit or surplus. In total, the net energy benefit in 1-reactor configuration is -20 million MJ/a. In Scenario 2 the total benefit is -26.9 million MJ/a, improving the energy surplus by $35 \%$. From this point, the AirPrex ${ }^{\circledR}$ system with 3-reactor configuration has better energy efficiency than the one with 1-reactor configuration due to the benefits of sludge disposal. It needs to be mentioned that, in Scenario 1 the $2 \%$ improvement of dewaterability is based on AMS sludge, but in Scenario 2, the improvement of dewaterability of $2.5 \%$ is based on AMS sludge with a different starting point of dry matter improvement.

For a better understanding of the environmental impact of one $\mathrm{kg}$ of recovered $\mathrm{P}$, the total cumulative energy demand is also calculated for the function unit per $\mathrm{kg}$ of produced phosphorus (Figure 5). In scenario 1 and scenario 2 the harvested $\mathrm{P}$ in struvite is $34198 \mathrm{~kg} / \mathrm{a}$ and $55243 \mathrm{~kg} / \mathrm{a}$ respectively. It can be observed that 3-reactor configuration has a lower energy and chemical demand per $\mathrm{kg}$ P for its AirPrex ${ }^{\circledR}$ reactor. The energy surplus is less than the one with 1-reactor configuration due to a much higher $\mathrm{P}$ harvested in struvite. In total, the net energy credits in 1-reactor configuration are $-586 \mathrm{MJ} / \mathrm{kg} \mathrm{P}$ and with 3-reactor configuration are $-487 \mathrm{MJ} / \mathrm{kg} \mathrm{P}$. It is worth noting that the surplus of energy comes from sludge dewatering, polymer saving and disposal benefits, which is not directly related to the produced amount of $\mathrm{P}$. Thus, considering the average demand for energy per $\mathrm{kg} \mathrm{P}$ and the amount of phosphorus produced, the new reactor shows a better performance. 


\section{- Global Warming Potential (GWP)}

Global warming potential (GWP) is typically closely related to fossil energy demand, as greenhouse gases are mainly emitted from the combustion of fossil fuels (Remy et al., 2015). The $\mathrm{CO}_{2}$ footprints in this study include fossil $\mathrm{CO}_{2}, \mathrm{~N}_{2} \mathrm{O}, \mathrm{CH}_{4}$. The additional AiPrex ${ }^{\circledR}$ reactor and $\mathrm{MgCl}_{2}$ production caused an increased impact of approximately 1 million and 0.5 million $\mathrm{kg} \mathrm{CO}_{2}$-eq (Figure 6). The negative net impact means the equivalent $\mathrm{CO}_{2}$ emissions are reduced in relation to the reference state. These shares are caused by the monoincineration plant, polymer, electricity for return load, WWTP and the credits of P- and Nfertilizer. The major credits in the system come from the mono-incineration plant (heating, natural gas and electricity produced). If the sludge disposal was not considered, the net values would be positive.

In total, Scenario 2 has a net GWP of -1.9 million $\mathrm{kg} \mathrm{CO}_{2}$-eq and Scenario 1 has 1.4 million kg CO 2 -eq. In Scenario 2 about 36\% equivalent $\mathrm{CO}_{2}$ emissions are reduced. Regarding the FU per kg produced $\mathrm{P}$, net impacts are $-41.8 \mathrm{~kg} \mathrm{CO}$-eq/kg P (Scenario 1) and -34.9 $\mathrm{kg} \mathrm{CO}_{2^{-}}$ eq/kg P (Scenario 2).

\section{- Fresh Water Eutrophication Potential (FEP)}

Freshwater eutrophication (FEP) is caused by phosphorus emissions. As shown in Figure 7, reduction in FEP is mainly related to direct reduction of $\mathrm{P}$ emissions from the mainstream WWTP. Other factors e.g. production of electricity for the AirPrex ${ }^{\circledR}$ reactor (P emissions caused by raw material mining), saved electricity in mono-incineration and substitution of mineral $\mathrm{P}$ fertilizer production (which is associated with $\mathrm{P}$ emissions into water) also contribute to the total results, though to a lesser degree.

In the model of simplified wastewater treatment plant, the removal rate of phosphorus is defined. Therefore, a higher influent concentration may cause higher emissions under this hypothetical condition. The AirPrex ${ }^{\circledR}$ system reduce the $\mathrm{P}$ from sludge liquid, thus reducing the considerable $\mathrm{P}$ return load to the mainstream WWTP and consequently its direct $\mathrm{P}$ emissions. Hence, totally, FEP can be reduced in AirPrex ${ }^{\circledR}$ Scenario 1 by $-912 \mathrm{~kg} \mathrm{P-eq} / \mathrm{a}$ and in Scenario 2 by $-1064 \mathrm{~kg}$ P-eq/a. Overall, Scenario 2 has a higher reduction (16.7\%) of $\mathrm{P}$ emissions than Scenario 1 and this is mainly due to the higher P-harvesting in sludge and therefore lower residual phosphate in return loads. Regarding the FU per kg of recovered $\mathrm{P}$, in Scenario 1 the FEP can be can reduced by $0.0267 \mathrm{~kg}$ P-eq/kg of recovered $\mathrm{P}$ and in Scenario 2 by $-0.0193 \mathrm{~kg}$ P-eq/ kg of recovered P. 


\section{- Marine Eutrophication Potential (MEP)}

Marine eutrophication is caused by nitrogen emissions. As shown in Figure 8, the dominating impacts of MEP are the emission from the AirPrex ${ }^{\circledR}$ reactor and the discharge by the WWTP.

The AirPrex ${ }^{\circledR}$ reactor in 1-reactor configuration is uncovered and part of in the ammonia gas in digested sludge is discharged directly into air. Calculation the ammonia concentration in the sludge before and after AirPrex ${ }^{\circledR}$, about $8 \%$ of ammonia was emitted into the atmosphere. The aeration reactor in 3-reactor configuration is closed and the off gas is treated in a biofilter and therefore a $2 \%$ loss is taken into account. In scenario 1 , the benefit of return load reduction $\left(15481 \mathrm{~kg} \mathrm{~N}\right.$-eq per year) is offset by the ammonia emission from the AirPrex ${ }^{\circledR}$ reactor $(18,908 \mathrm{~kg} \mathrm{~N}$-eq per year), and finally with a total net impact of $2,357 \mathrm{~kg} \mathrm{~N}$-eq per year. Scenario 2 emits 4,727 kg N-eq per year into the air and reduces 17,878 $\mathrm{kg} \mathrm{N}$-eq per year from the return load. Thus, a net redution of $14,615 \mathrm{~kg} \mathrm{~N}$-eq per year is achieved in scenario 2. The net impacts per $\mathrm{kg} \mathrm{P}$ are $0.069 \mathrm{~kg} \mathrm{~N}$-eq/kg P and $-0.264 \mathrm{~kg} \mathrm{~N}$-eq/kg P. Thus, scenario 2 has improved the marine eutrophication impact significantly due to the lower ammonia gas emissions and lower nitrogen concentration in the return load.

\section{Conclusion}

In this study, LCA is used to compare 1-reactor system versus 3-reactor system of AirPrex ${ }^{\circledR}$ process and to find an orientation towards environmentally friendly reactor system. In the following, the most important findings are summarized.

Compared to the reference system, which is defined as the sludge line treating the mixed sludge at WWTP Wassmannsdorf, both AirPrex ${ }^{\circledR}$ configurations have positive energy benefits and better environmental credits for the GWP, FEP, and MEP. The most important contributors to the energy impacts in 3-reactor configuration are electricity for AirPrex ${ }^{\circledR}$ reactor $(62.6 \%)$ and production of magnesium chloride $(36.5 \%)$ while the main energy benefits are from the heat for district heating to substitute natural gas (40.2\%), electricity production in mono-incineration (20.9\%), reduced polymer demand $(17.5 \%)$, the substitution of conventional $\mathrm{N}$ and P-fertilizer (10\%) and the reduced electricity for return load (3.5\%).

The AMS reactor shows better results in cumulative energy demand with $35 \%$ improvement of energy surplus, 36\% reduction of global warming potential and lower eutrophication potential. The different results of both scenarios are mainly caused by the reactor design and the harvesting efficiency. The 3-reactor configuration has a better separation of crystals from the sludge due to a better crystallization condition in the first two reactors and an additional quiet condition for struvite precipitation in the third reactor. The higher the amount of struvite 
recovered, the more $\mathrm{P}$ - and $\mathrm{N}$-fertilizer credits can be achieved. The TS improvement of dewatering in 3-reactor configuration has the most important impact on the CED and GWP benefits while the return load of WWTP. Ammonia gas emissions have the most important impact on the MEP.

It is suggested that, when installing a new AirPrex ${ }^{\circledR}$ reactor, the 3-reactor configuration is recommended due to a higher struvite yield and a better environmental impact. Although the investment of 3-reactor configuration is ca. 30\% higher than 1-reactor configuration, the additional investment can be returned through operational savings within 1 to 2 years. In WMD, the $\mathrm{NH}_{3}$ emissions into the air can be reduced by instilling a biofilter. At the same time, it is also important to mention that, the further development of technology, e.g. AirPrex ${ }^{\circledR}$, can be practiced not only in the laboratory or pilot plant but also in full-scale operation.

\section{Acknowledgements}

At this point we would like to acknowledge all persons involved in the project P-REX and the WWTP operators and colleagues, who helped us to conduct this study. And especially thanks to Alex Veltman of Waternet at WWTP Amsterdam West and Andreas Lengemann, Bernd Heinzmann of Berliner Wasserbetriebe at WWTP Wassmannsdorf; Fabian Kraus and Ulf Miehe from the Berlin Centre of Competence for Water. P-REX was financially supported by the European Commission (FP7 project P-REX, Grant agreement \#308645). 


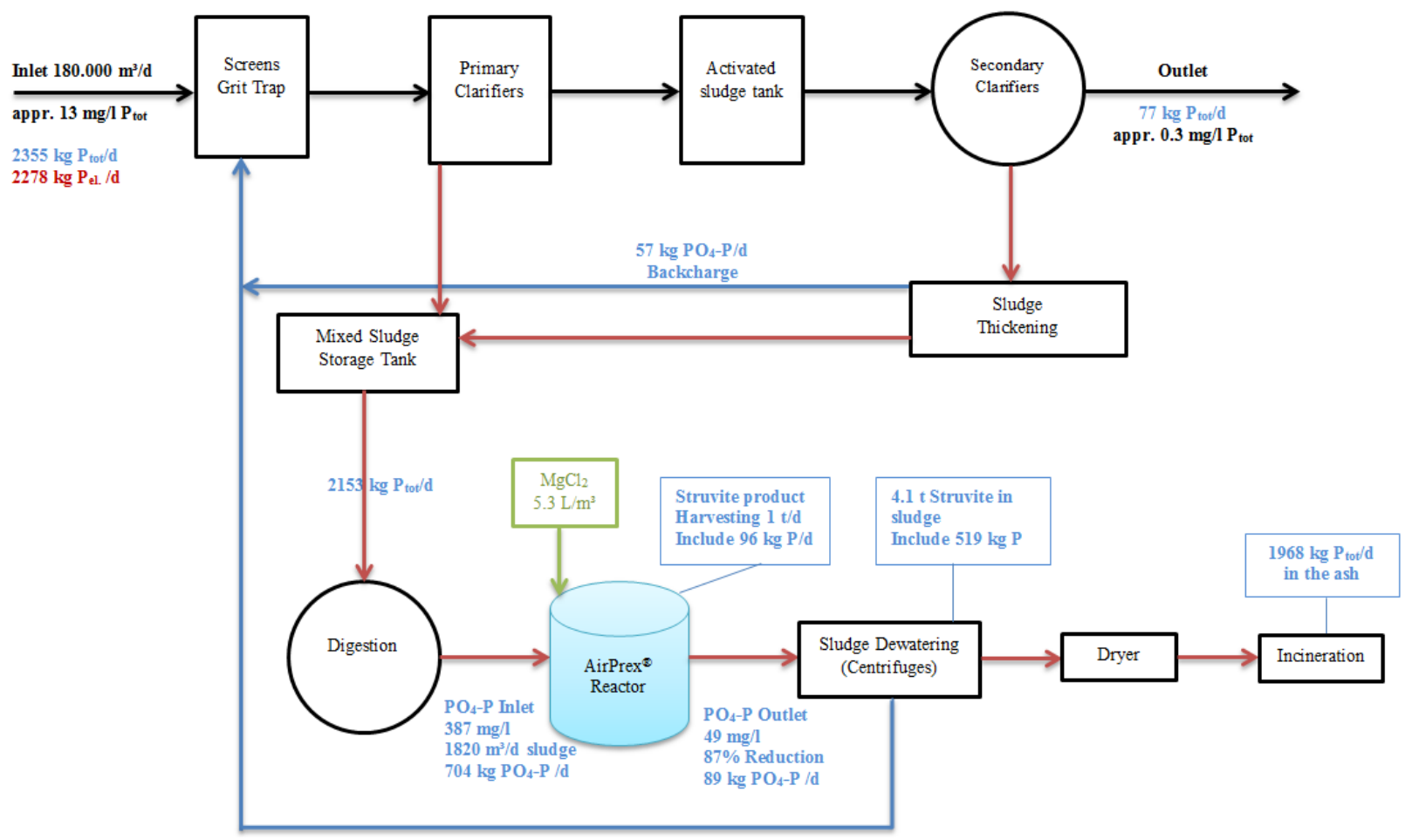

Figure 1: Process scheme and P mass balance of WWTP Wassmannsdorf (modified) (Forstner, 2015)

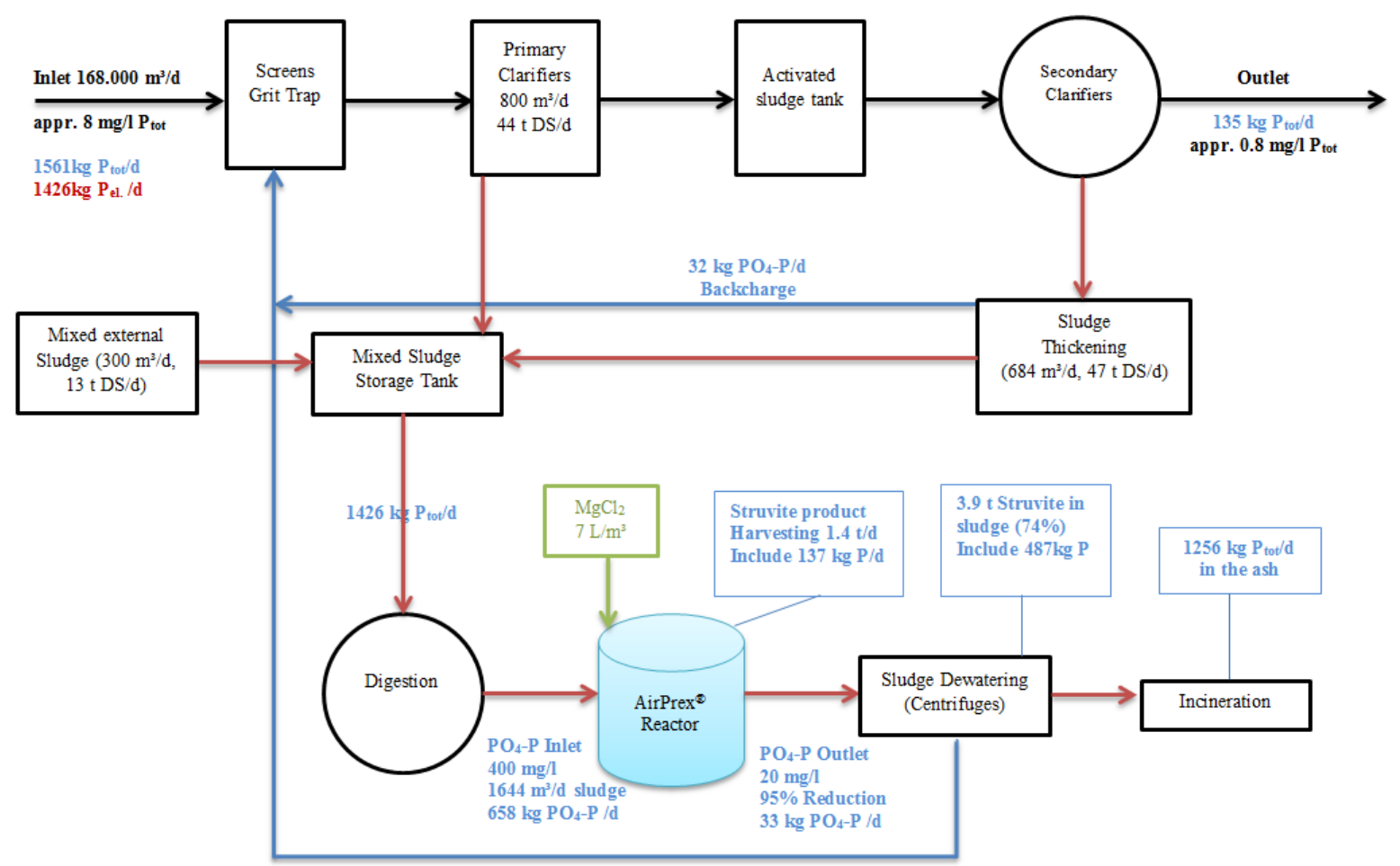

Figure 2: Process scheme and P mass balance of WWTP Amsterdam West (modified) (Forstner, 2015) 


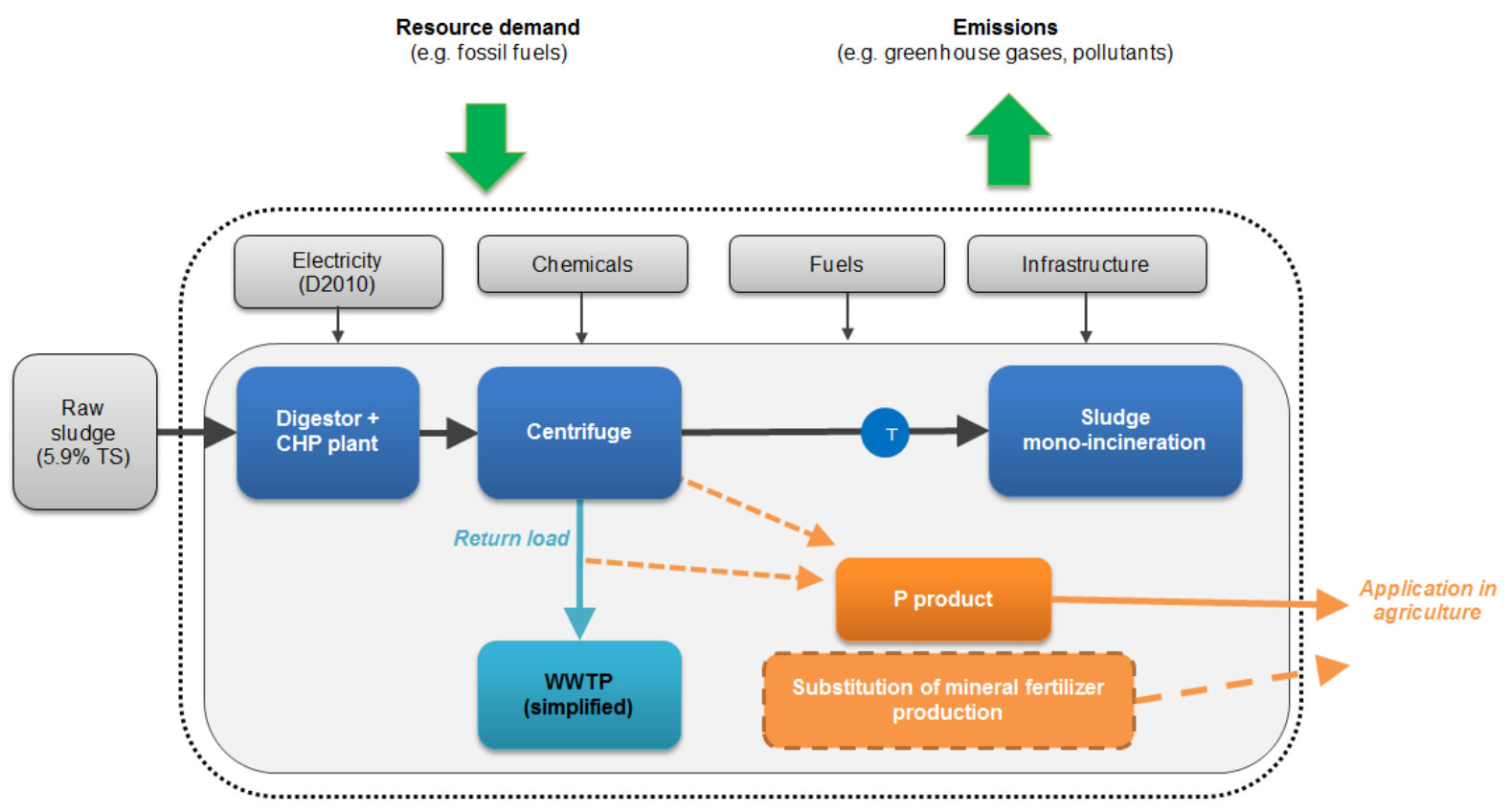

Figure 3: System Boundary of the LCA (Remy et al., 2015)

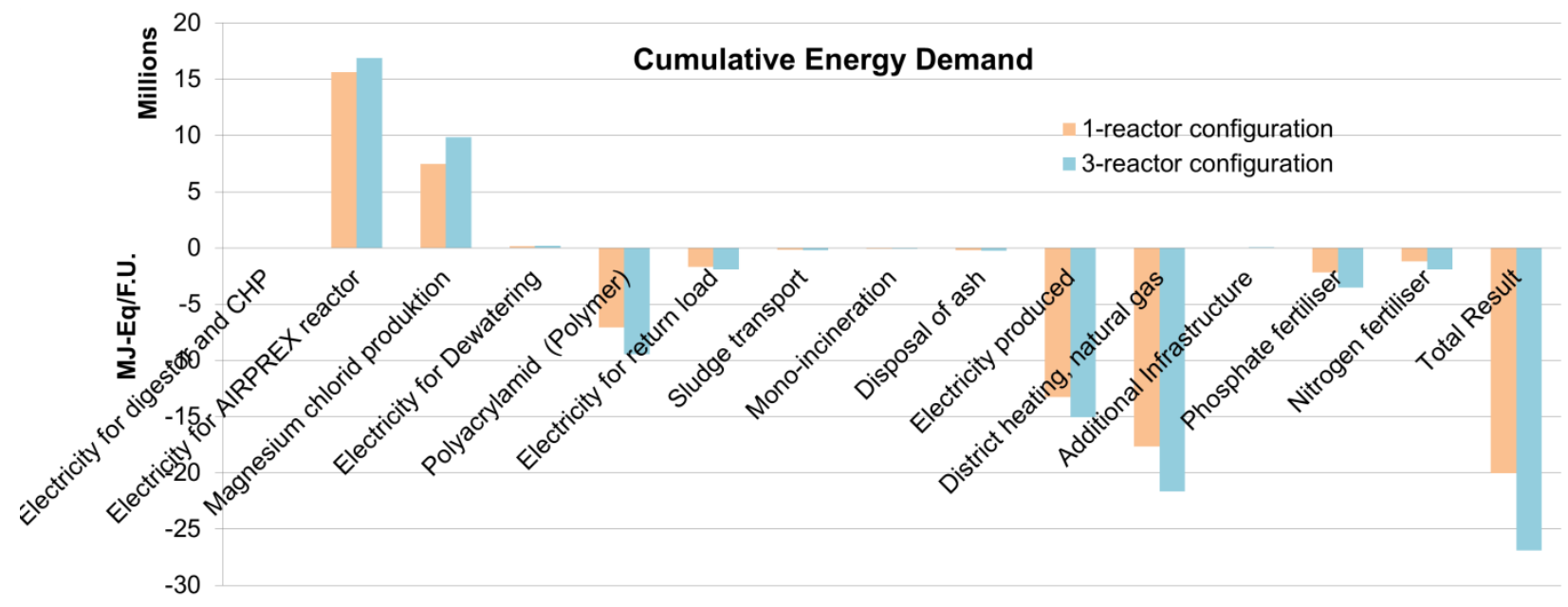

Figure 4: Total Cumulative Energy Demand of AirPrex ${ }^{\circledR}$ system with 1-reactor and 3-reactor configuration 


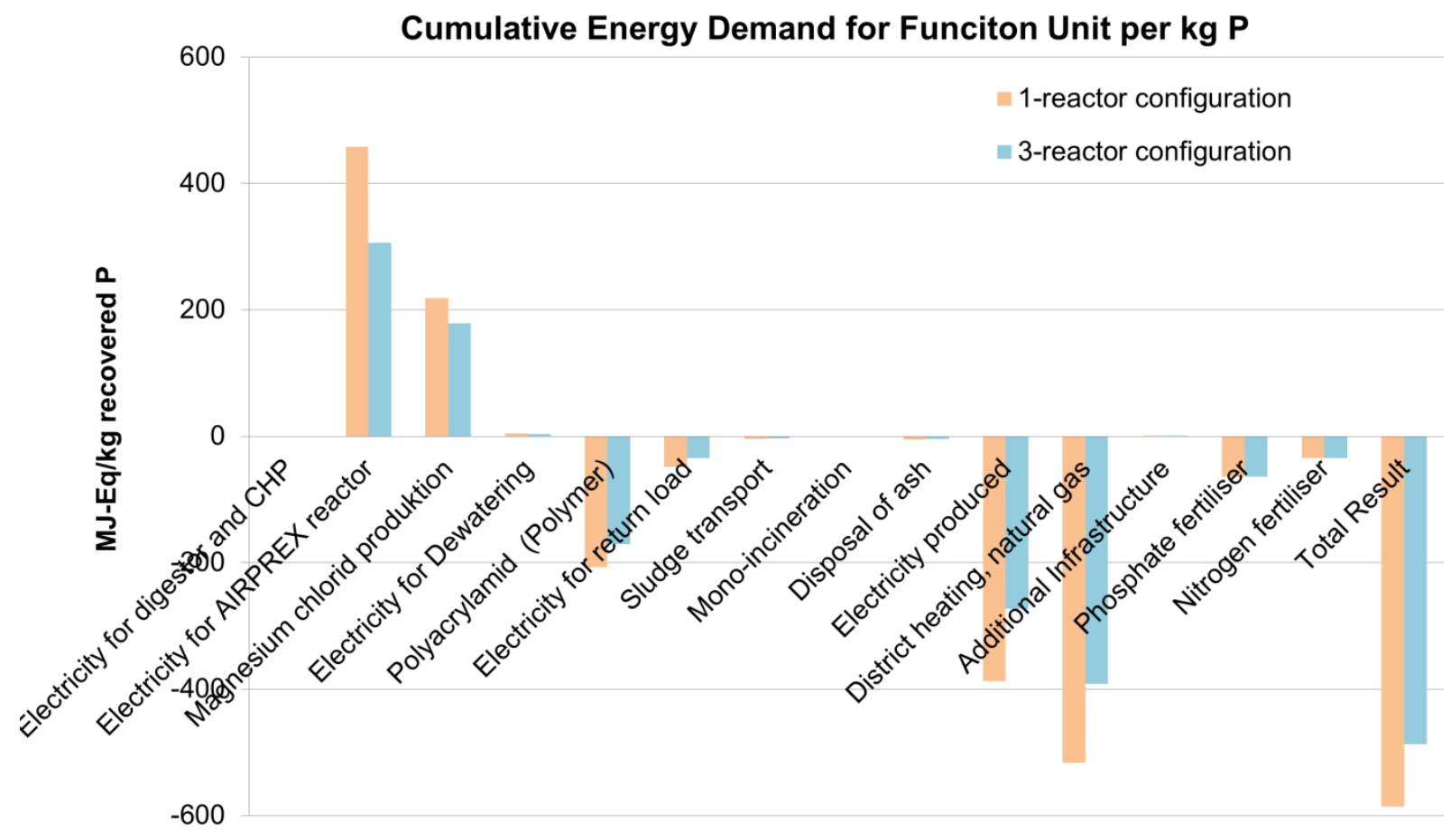

Figure 5: Total Cumulative Energy Demand for FU per kg P production

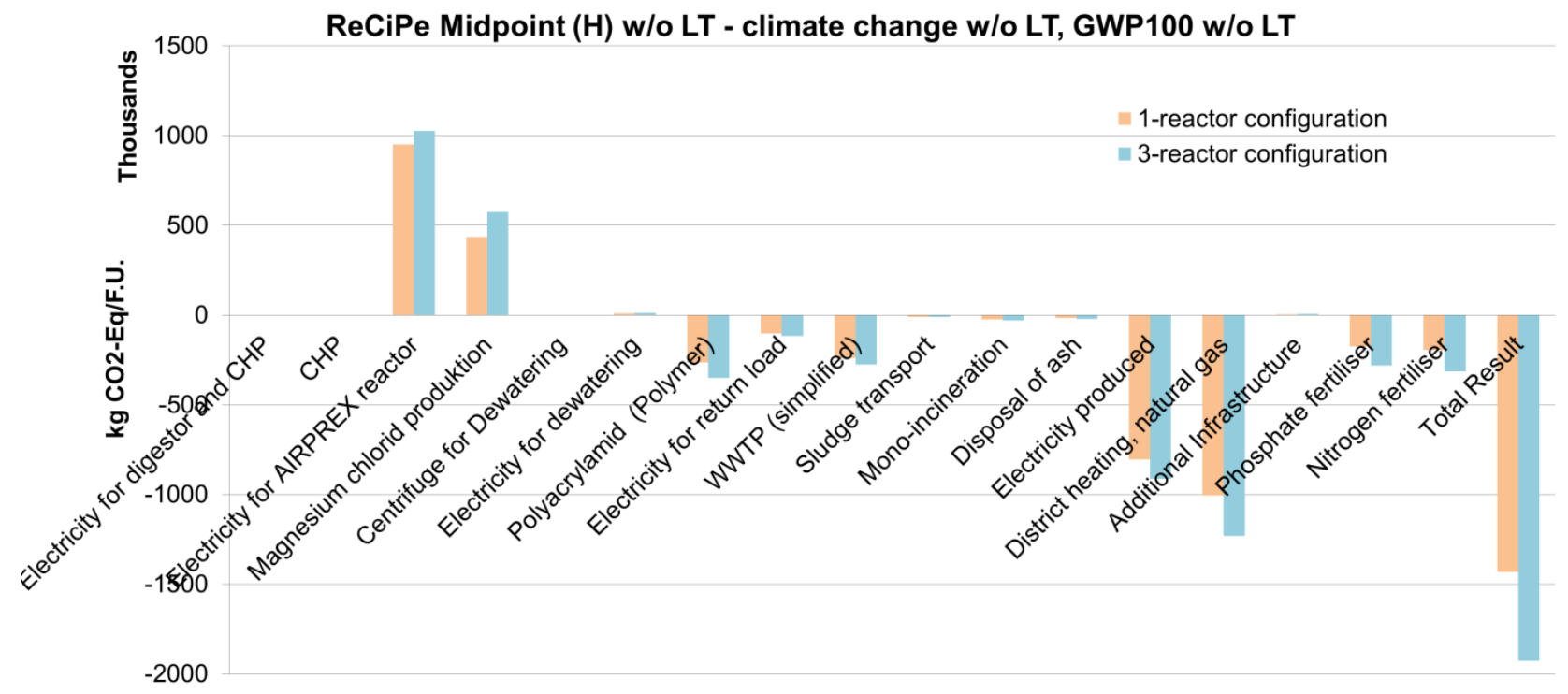

Figure 6: Global Warming Potential ("w/o LT" means "without long-term emissions") 


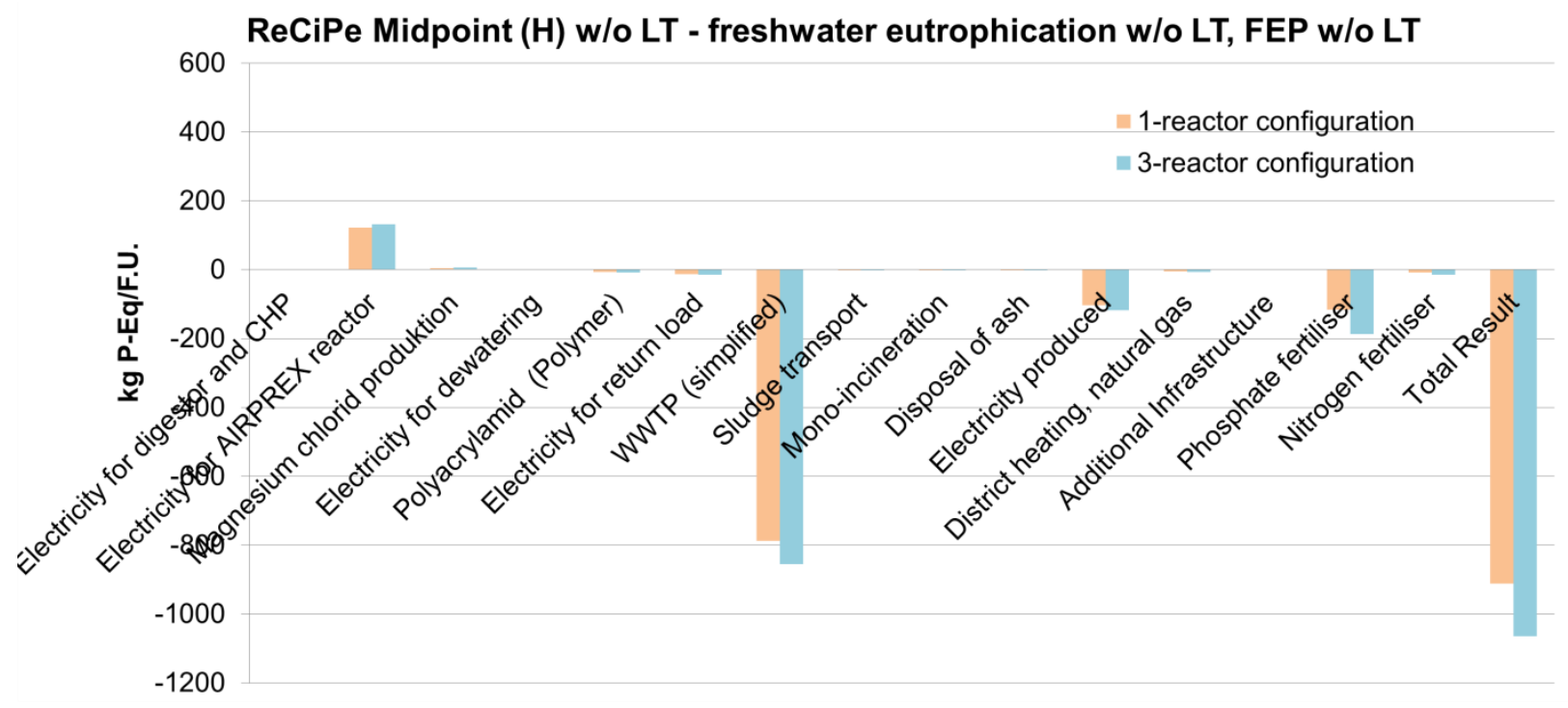

Figure 7: Freshwater Eutrophication Potential

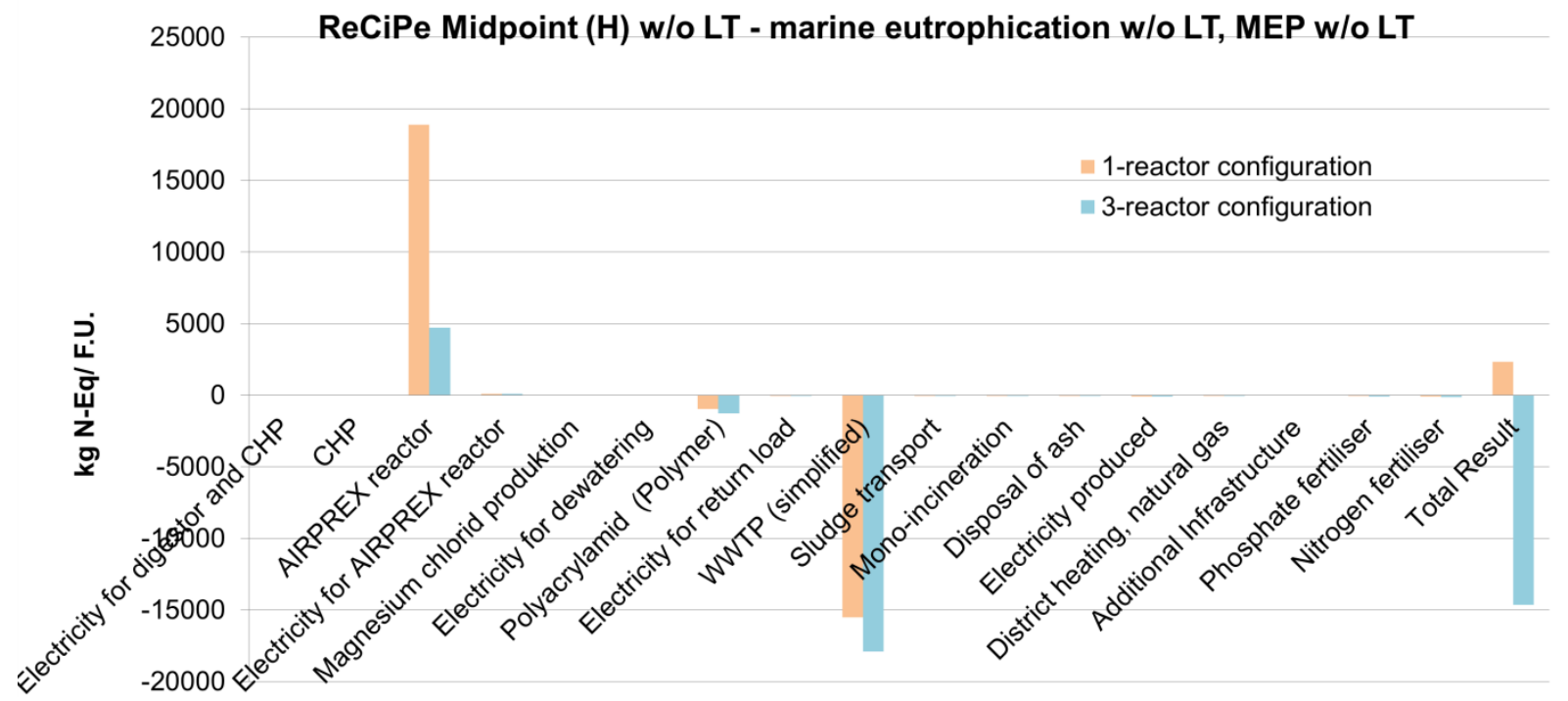

Figure 8: Marine Eutrophication Potential 
Table 1: Comparison of AirPrex ${ }^{\circledR}$ Systems in WWTP Wassmannsdorf and Amsterdam West (Wendl, 2013, Veltman, 2016, Lengemann, 2017)

\begin{tabular}{|c|c|c|c|}
\hline \multicolumn{4}{|c|}{ WWTP } \\
\hline & Unit & $\begin{array}{c}\text { WWTP } \\
\text { Wassmannsdorf }\end{array}$ & $\begin{array}{c}\text { WWTP Amsterdam } \\
\text { West }\end{array}$ \\
\hline Person equivalent & p.e. & $1,400,000$ & $1,000,000$ \\
\hline Sludge volume & $\mathrm{m}^{3} / \mathrm{a}$ & 664,300 & 600,000 \\
\hline TSS & $\%$ & 5.89 & 6 \\
\hline TS sludge & $\mathrm{t} / \mathrm{a}$ & 39,127 & 36,000 \\
\hline \multicolumn{4}{|c|}{ AirPrex reactor } \\
\hline Dissolved $\mathrm{PO}_{4}-\mathrm{P}$ Input & $\mathrm{mg} / \mathrm{l}$ & 387 & 400 \\
\hline Dissolved $\mathrm{PO}_{4}-\mathrm{P}$ Output & $\mathrm{mg} / \mathrm{l}$ & 49 & 19 \\
\hline $\begin{array}{l}\mathrm{PO}_{4}-\mathrm{P} \text { Precipitation } \\
\text { efficiency }\end{array}$ & $\%$ & 87 & 95 \\
\hline $\mathrm{MgCl}_{2}$ dosing & $\begin{array}{c}\mathrm{mol} \\
\mathrm{Mg} / \mathrm{mol} \mathrm{P}\end{array}$ & 1.7 & 1.9 \\
\hline $\begin{array}{l}\text { Sludge hydraulic } \\
\text { residence time in all } \\
\text { reactors }\end{array}$ & $\mathrm{h}$ & 10.5 & 8 \\
\hline Air pumping & $\mathrm{m}^{3} / \mathrm{h}$ & 2500 & 1000 \\
\hline Energy Demand & $\mathrm{kWh} / \mathrm{m}^{3}$ & 2.2 & 2.4 \\
\hline \multicolumn{4}{|c|}{ Sludge Dewatering } \\
\hline TS improvement & $\%$ & $\begin{array}{c}2 \% \\
\text { (from } 25 \% \text { to } 27 \% \text { ) }\end{array}$ & $\begin{array}{c}2.5 \% \\
\text { (from } 21 \% \text { to } 23.5 \% \text { ) }\end{array}$ \\
\hline Polymer Saving & $\mathrm{g} / \mathrm{kg}$ TSS & $\begin{array}{c}3 \\
\text { (from12 to } 9) \\
\end{array}$ & $\begin{array}{c}4 \\
\text { (from } 17 \text { to } 13 \text { ) }\end{array}$ \\
\hline \multicolumn{4}{|c|}{ Struvite Harvesting } \\
\hline Product harvesting & ton/a & 360 & 500 \\
\hline $\begin{array}{l}\text { Share of struvite in total } \\
\text { solids product }\end{array}$ & $\%$ & 78 & 80 \\
\hline $\begin{array}{l}\text { Harvesting efficiency } \\
\text { ( } \mathrm{P} \text { in Product/dissolved } \mathrm{P} \\
\text { in sludge) }\end{array}$ & $\%$ & $14 \%$ & $21 \%$ \\
\hline
\end{tabular}




\section{Supplementary material}

Table S1: List of full-scale AirPrex ${ }^{\circledR}$ technology $(C N P, 2017)$

\begin{tabular}{|l|c|c|c|c|c|}
\hline \multicolumn{1}{|c|}{ Country } & Location and Operator & $\begin{array}{c}\text { Operational } \\
\text { since }\end{array}$ & $\begin{array}{c}\text { Personal } \\
\text { equivalent }\end{array}$ & $\begin{array}{c}\text { Capacity } \\
\text { of } \\
\text { AirPrex }\end{array}$ & $\begin{array}{c}\text { Design } \\
\text { struvite } \\
\text { production }\end{array}$ \\
\hline Germany & $\begin{array}{c}\text { MG-Neuwerk, } \\
\text { Niersverband }\end{array}$ & 2009 & 995,000 & 1500 & 1000 \\
\hline Germany & $\begin{array}{c}\text { Wassmannsdorf, } \\
\text { Berliner Wasserbetriebe }\end{array}$ & 2010 & $1,400,000$ & 2400 & 2000 \\
\hline Netherlands & $\begin{array}{c}\text { Echten, } \\
\text { Drents Overijsselse Delta }\end{array}$ & 2013 & 190,000 & 400 & 500 \\
\hline Netherlands & $\begin{array}{c}\text { Amsterdam-West, } \\
\text { Waternet }\end{array}$ & 2014 & $1,000,000$ & 2500 & 3500 \\
\hline Germany & $\begin{array}{c}\text { Uelzen, } \\
\text { SE Uelzen }\end{array}$ & 2015 & 83,000 & 145 & n.a. \\
\hline Germany & $\begin{array}{c}\text { Salzgitter Nord, } \\
\text { ASG }\end{array}$ & 2015 & 150,000 & 240 & n.a. \\
\hline Germany & $\begin{array}{c}\text { Wolfsburg, } \\
\text { SE Wolfsburg }\end{array}$ & 2016 & 170,000 & 280 & n.a. \\
\hline China & $\begin{array}{c}\text { Tianjin, } \\
\text { Tianjin CEPG }\end{array}$ & 2016 & $1,000,000$ & 1600 & n.a. \\
\hline
\end{tabular}

(n.a. = not accessible)

Table S2: Site Specific Data for reference system at WWTP Wassmannsdorf 2016 (Lengemann, 2017)

\begin{tabular}{|l|c|c|c|c|}
\hline \multicolumn{5}{|c|}{ Anput mixed sludge } \\
\hline \multicolumn{1}{|c|}{ Parameter } & Value & Unit & Value & Unit \\
\hline Volume & 664,300 & $\mathrm{~m}^{3} / \mathrm{a}$ & & \\
\hline Dry matter & $39,127,270$ & $\mathrm{~kg} / \mathrm{a}$ & 5.89 & $\%$ \\
\hline Organic dry matter & $3,208,436$ & $\mathrm{~kg} / \mathrm{a}$ & 82 & $\%$ of dry matter \\
\hline COD & $30,816,877$ & $\mathrm{~kg} / \mathrm{a}$ & 4639 & $\mathrm{mg} / \mathrm{l}$ \\
\hline Total nitrogen & $2,120,698$ & $\mathrm{~kg} / \mathrm{a}$ & 54.2 & $\mathrm{mg} / \mathrm{kg}$ \\
\hline Phosphorus & $1,074,044$ & $\mathrm{~kg} / \mathrm{a}$ & 27.45 & $\mathrm{mg} / \mathrm{kg}$ \\
\hline
\end{tabular}


Table S3: Reference Data for Digester and CHP (Remy, 2012)

\begin{tabular}{|l|c|l|}
\hline \multicolumn{2}{|c|}{ Digester } \\
\hline \multicolumn{1}{|c|}{ Parameter } & Value & \multicolumn{1}{c|}{ Unit } \\
\hline VSS degradation & 47 & $\%$ \\
\hline Biogas yield & 423 & $\mathrm{NL} / \mathrm{kg} \mathrm{V} \mathrm{SS}_{\text {In }}$ \\
\hline Biogas $\mathrm{CH}_{4}$ content & 60.5 & Vol-\% $\mathrm{CH}_{4}$ \\
\hline Electricity demand & 4.1 & $\mathrm{kWh} / \mathrm{m}^{3}$ Sludge \\
\hline Heat demand & 20 & $\mathrm{kWh} / \mathrm{m}^{3}$ Sludge \\
\hline \multicolumn{2}{|c|}{ CHP } & $\%$ \\
\hline Efficiency electric & 36 & $\%$ \\
\hline Efficiency thermal & 44 & $\%$ of Biogas \\
\hline $\mathrm{CH}_{4}$ leakage & 0.75 & $\%$ of Biogas \\
\hline $\mathrm{CH}_{4}$ to flare & 0.01 & $\mathrm{kWh} / \mathrm{m}^{3}$ Biogas \\
\hline $\begin{array}{l}\text { Electricity demand for gas purification and } \\
\text { CHP plants }\end{array}$ & 0.156 & \\
\hline
\end{tabular}

Table S4: Specific Data for AirPrex ${ }^{\circledR}$ Scenarios (Lengemann, 2017, Veltman, 2016)

\begin{tabular}{|l|c|c|c|}
\hline \multicolumn{3}{|c|}{ AirPrex $^{\circledR}$} \\
\hline Throughput & Unit & $\begin{array}{c}\text { Scenario 1 } \\
\text { WMD }\end{array}$ & $\begin{array}{c}\text { Scenario 2 } \\
\text { AMS }\end{array}$ \\
\hline Retention time & $\mathrm{m}^{3}$ per da & 1820 & 1820 \\
\hline $\begin{array}{l}\text { PO }_{4}-\mathrm{P} \text { Precipitation } \\
\text { efficiency }\end{array}$ & $\mathrm{h}$ & 10.5 & 8 \\
\hline $30 \% \mathrm{MgCl}_{2}$ dosing & $\%$ & 87 & 95 \\
\hline Air pumping & $1 / \mathrm{m}^{3}$ & 5.3 & 7 \\
\hline Energy Demand & $\mathrm{m}^{3} / \mathrm{h}$ & 2500 & 1000 \\
\hline Harvesting efficiency & $\mathrm{kWh} / \mathrm{m}^{3}$ & 2.2 & 2.4 \\
\hline P in recovered struvite & $\mathrm{kg} / \mathrm{a}$ & 14 & 21 \\
\hline $\mathrm{N}_{\text {in recovered struvite }}$ & $\mathrm{kg} / \mathrm{a}$ & 34198 & 24985 \\
\hline $\mathrm{NH}_{4}$-N emission & $\%$ & 15467 & 2 \\
\hline
\end{tabular}


Table S5: Specific Data for Decanter (Veltman, 2016, Jossa, 2014)

\begin{tabular}{|l|c|c|c|c|}
\hline \multicolumn{5}{|c|}{ Sludge Dewatering } \\
\hline & \multicolumn{3}{|c|}{ Value } & Unit \\
\hline & Reference & Scenario 1 & Scenario 2 & \\
\hline Final TS & 25 & 27 & 27.5 & $\%$ \\
\hline Decanter electricity demand & 3.8 & 3.8 & 3.8 & $\mathrm{kWh} / \mathrm{m}^{3}$ sludge \\
\hline Polymer Demand & 12 & 9 & 8 & $\mathrm{~g} / \mathrm{kg}$ TSS \\
\hline
\end{tabular}

Table S6: Reference Data for simplified WWTP (Remy, 2012)

\begin{tabular}{|l|c|c|}
\hline \multicolumn{3}{|c|}{ Simplified WWTP } \\
\hline & Value & Unit \\
\hline Energy Demand Aeration & 0.5 & $\mathrm{kWh} / \mathrm{kg} \mathrm{O}$ \\
\hline Energy Demand EBPR & 0.37 & $\mathrm{kWh} / \mathrm{kg} \mathrm{P}$ \\
\hline Energy Demand N-removal & 1 & $\mathrm{kWh} / \mathrm{kg} \mathrm{N}$ \\
\hline
\end{tabular}

Table S7: Reference Data for Return Load (Lengemann, 2017)

\begin{tabular}{|l|c|c|c|c|}
\hline \multicolumn{5}{|c|}{ Return Load } \\
\hline & Reference & Scenario 1 & Scenario 2 & Unit \\
\hline $\mathrm{TSS}$ & 520 & 520 & 520 & $\mathrm{mg} / \mathrm{l}$ \\
\hline $\mathrm{NH}_{4}-\mathrm{N}$ & 1286 & 1137 & 1124 & $\mathrm{mg} / \mathrm{l}$ \\
\hline $\mathrm{PO}_{4}-\mathrm{P}$ & 387 & 49 & 19 & $\mathrm{mg} / \mathrm{l}$ \\
\hline
\end{tabular}

Table S8: Reference Data for Mono Incineration (Remy et al., 2015)

\begin{tabular}{|l|c|c|}
\hline & Value & Unit \\
\hline Heating Value VSS & 14 & $\mathrm{MJ} / \mathrm{kg}$ \\
\hline Water Evaporation & -2.6 & $\mathrm{MJ} / \mathrm{kg}$ \\
\hline Thermal Energy Conversion Efficiency & 73 & $\%$ \\
\hline Electrical Energy Conversion Efficiency & 14 & $\%$ \\
\hline Electricity Demand for Operation & 0.23 & $\mathrm{kWh} / \mathrm{kg} \mathrm{TS}$ \\
\hline
\end{tabular}




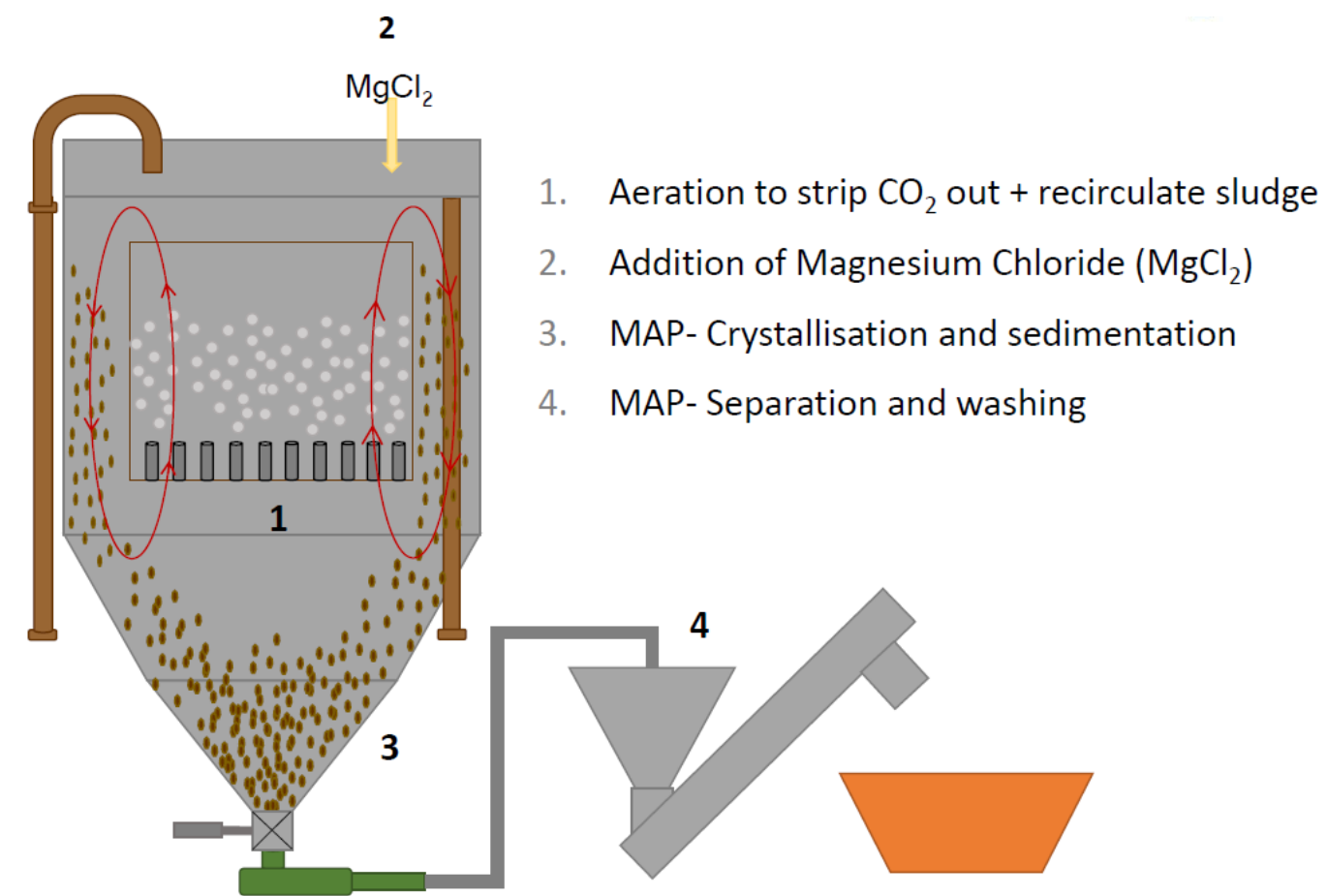

Figure S1: Principe of AirPrex ${ }^{\circledR}$ technology ${ }^{\circledR} \mathrm{CNP}$ (Forstner, 2015)
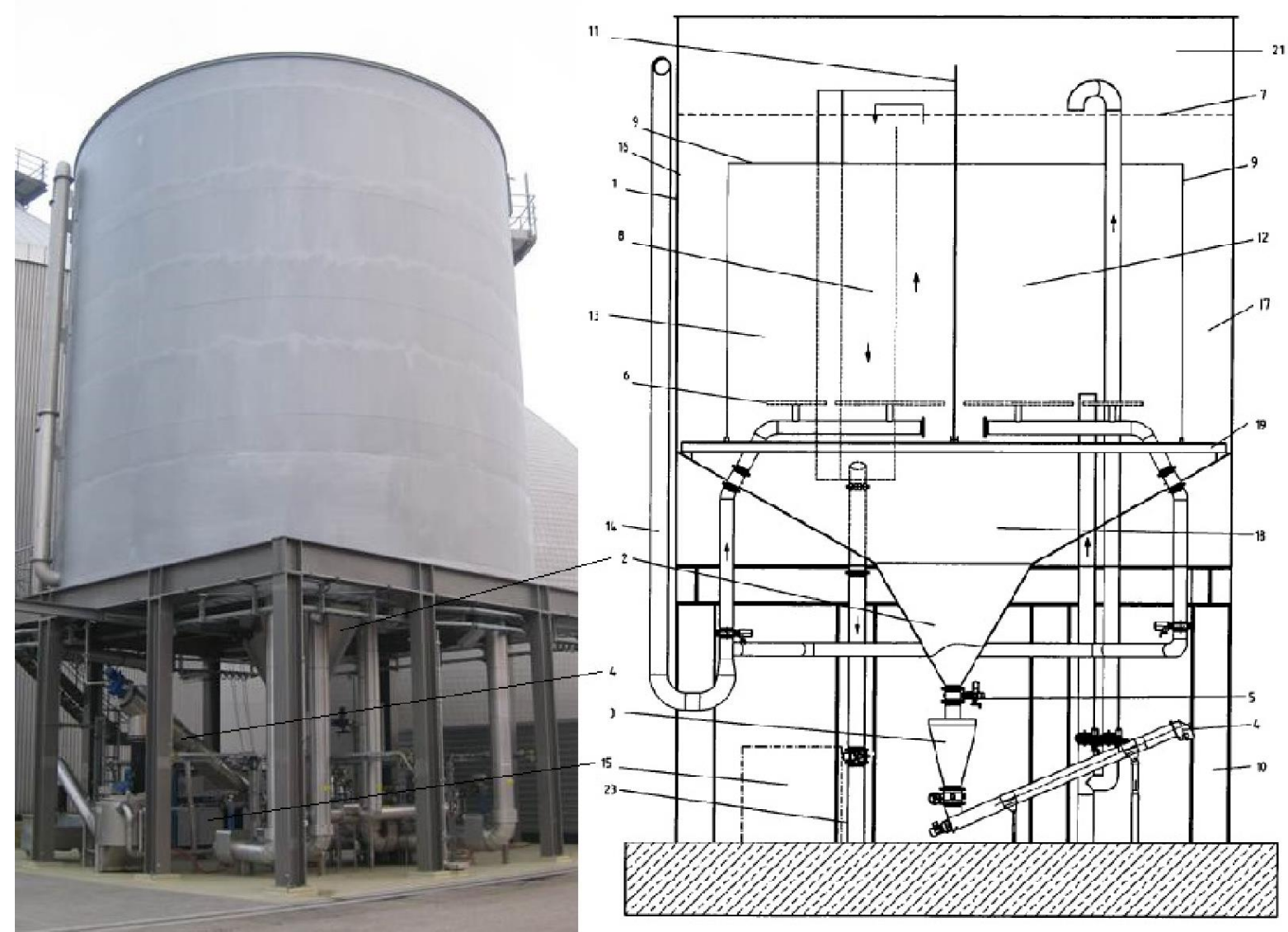

Figure S2: AirPrex ${ }^{\circledR}$ reactor at WWTP Wassmannsdorf (Wendl, 2013) 


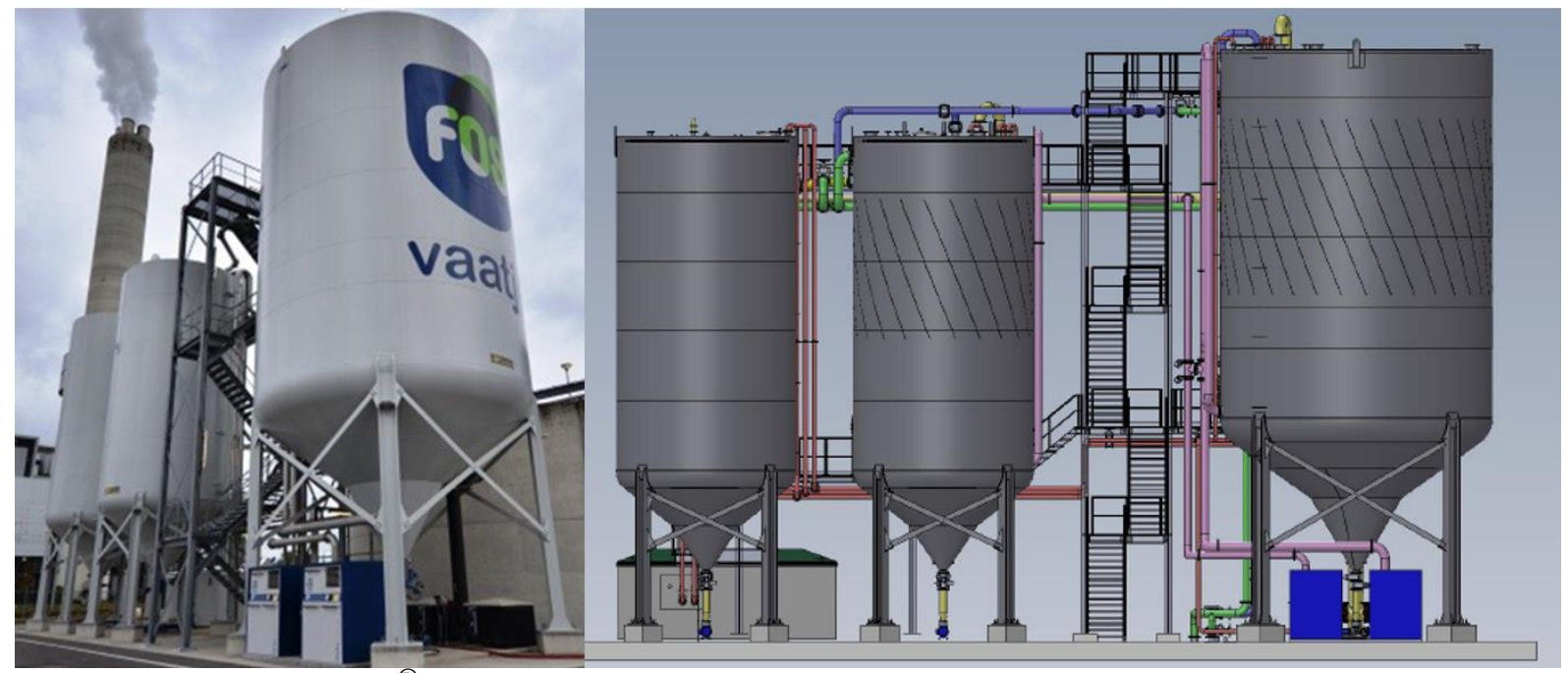

Figure S3: The Airprex ${ }^{\circledR}$ reactor at WWTP Amsterdam west (Veltman, 2016)

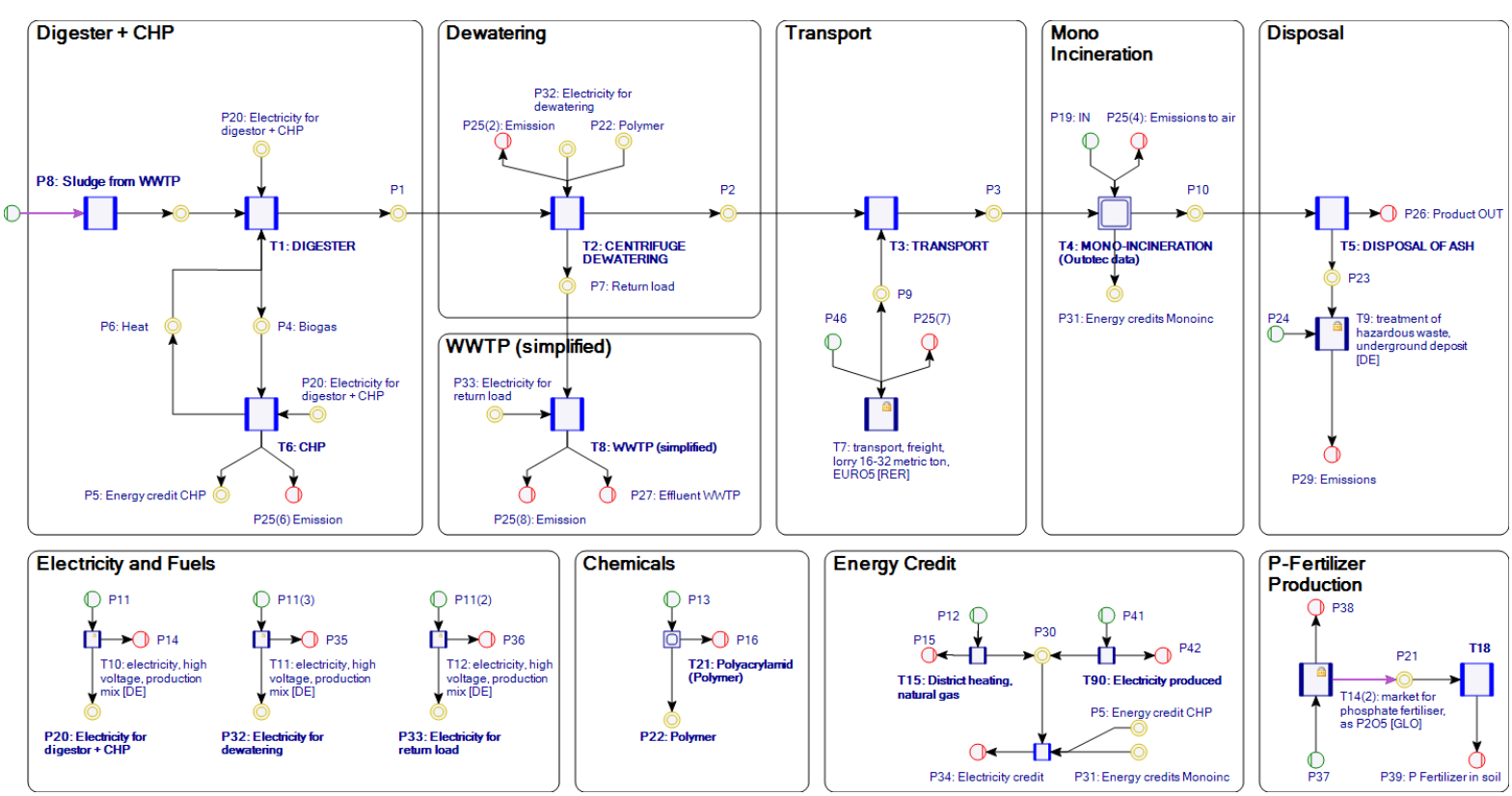

Figure S4: Reference system for Life Cycle Inventory analysis (Remy et al., 2015, Jossa, 2014) 


\section{Reference:}

AMANN, A., et al. 2018. Environmental impacts of phosphorus recovery from municipal wastewater. Resources, Conservation and Recycling, 130, 127-139.

ASIMOV, I. 1959. Life's bottleneck. The Magazine of Fantasy and Science Fiction, 16, 31-40.

BERGMANS, B. 2011. Struvite recovery from digested sludge At WWTP West. master thesis, Delft University of Technology.

BWB 2017a. The region is growing - the sewage treatment plant is also growing (in German). http://www.bwb.de/content/language1/html/19149.php [Retrieved May 25, 2018]: Berliner Wasserbetriebe.

BWB 2017b. Wastewater treatment plant Waßmannsdorf, State-of-the-art technology for wastewater treatment in Berlin (in German). http://www.bwb.de/content/language1/downloads/20170425_Datenblatt_KWWassmannsdorf-DE final.pdf [Retrieved May 25, 2018]: Berliner Wasserbetriebe.

CNP 2017. Projekt list of AirPrex process. https://www.cnp-tec.de/projekte/ [Retrieved May 25, 2018]: CNP-Technology Water and Biosolids

COROMINAS, L., et al. 2013. Life cycle assessment applied to wastewater treatment: state of the art. Water research, 47, 5480-5492.

EGLE, L. 2014. Phosphorus recovery from wastewater-Detailed process description, data base and results AirPrex ®. Vienna: Vienna University of Technology.

EGLE, L., et al. 2015. Overview and description of technologies for recovering phosphorus from municipal wastewater. Resources, Conservation and Recycling, 105, Part B, 325346.

FORSTNER, G. AirPrex ${ }^{\mathrm{TM}}$ : Biosolids Treatment Optimization Process with the option of Phosphate Recovery. MWEA - Annual Biosolids Conference on 2. March 2015, 2015 East Lansing.

GOEDKOOP, M., et al. 2009. ReCiPe 2008. A life cycle impact assessment method which comprises harmonised category indicators at the midpoint and the endpoint level, 1.

GRAHL, B. 2009. Ökobilanz (lca): Ein leitfaden für ausbildung und beruf, John Wiley \& Sons.

HEINZMANN, B. \& ENGEL, G. 2006. Induced magnesium ammonia phosphate precipitation to prevent incrustations and measures for phosphorus recovery. Water Practice and Technology, 1, 51.

HEINZMANN, B. \& LENGEMANN, A. State of phosphorus recovery in Berlin- From scientific investigations to large-scale application. Internationales Symposium "ReWater Braunschweig", 21. \& 22. November 20112011 Braunschweig, Germany (in German).

IFU 2017. Ecoinvent LCA database in Umberto NXT. https://www.ifu.com/en/umberto/ecoinvent-database/ [Retrieved May 25, 2018]: ifu Institut für Umweltinformatik Hamburg $\mathrm{GmbH}$.

ISO-14040 2006. Environmental management - Life Cycle Assessment - Principles and framework. Geneva, Switzerland: International Standardisation Organisation.

ISO-14044 2006. Environmental management - Life cycle assessment - Requirements and guidelines. Geneva, Switzerland: International Standardisation Organisation.

JOSSA, P. 2014. Phosphorus Recovery from Sewage Sludge: Comparison of Selected Processes Through Life Cycle Assessment. master thesis, Bauhaus-Universität Weimar.

KABBE, C. \& KRAUS, F. 2017. P recovery: from evolution to revolution. Fertilizer International, 479, 37-41.

KERN, J., et al. 2008. Recycling and assessment of struvite phosphorus from sewage sludge. Agricultural Engineering International: CIGR Journal. 
LENGEMANN, A. 2017. Laboratory measurement of digested sludge in WWTP Wassmansdorf (Internal data). Berliner Wasserbetriebe.

PENG, L., et al. 2018. A comprehensive review of phosphorus recovery from wastewater by crystallization processes. Chemosphere, 197, 768-781.

REMY, C. 2012. Project CoDiGreen Work package 2: LCA study of sludge treatment line in WWTP Berlin-Waßmannsdorf. http://www.kompetenz-wasser.de/wpcontent/uploads/2017/05/codigreen_lca_berlin_final.pdf [Retrieved May 25, 2018]: Kompetenzzentrum Wasser Berlin

REMY, C., et al. 2015. P-REX Deliverable D 9.2 Life Cycle Assessment of selected processes for $\mathrm{P}$ recovery from sewage sludge, sludge liquor, or ash. Sustainable sewage sludge management fostering phosphorus recovery and energy efficiency $(P$ $R E X)$. http://www.kompetenz-wasser.de/wp-content/uploads/2017/05/prex_d9_2_environmental_impact_assessment_lca_remy_2015.pdf [Retrieved May 25, 2018].

REMY, C., et al. 2012. Identifying energy and carbon footprint optimization potentials of a sludge treatment line with life cycle assessment. Water Science and Technology, 67, 63-73.

RULSEH, T. J. 2015. AirPrex Process Solves Struvite Problems. Treatment Plant Operator. http://www.tpomag.com/editorial/2015/10/airprex_process_solves_struvite_problems.

VDI 2012. Cumulative energy demand-Terms, Definitions, Methods of Calculation. VDIGuideline 4600: 2012-01. Berlin, Germany: Beuth Verlag

VELTMAN, A. Struvite recovery case Amsterdam West. ARREAU Struvite Recovery \& Recycling Learning Alliance kick-off slides on 16 June 2016, 2016 Amsterdam. EIP WATER.

WENDL, A.-T. 2013. Investigations on the technical and economic optimization of the operation of the MAP plant in Waßmannsdorf wastewater treatment plant (in German). master thesis, Brandenburgische Technische Universität.

WENZEL, H., et al. 2008. Weighing environmental advantages and disadvantages of advanced wastewater treatment of micro-pollutants using environmental life cycle assessment. Water Science and Technology, 57, 27-32.

ZHOU, K., et al. 2017. Phosphorus recovery from municipal and fertilizer wastewater: China's potential and perspective. Journal of Environmental Sciences, 52, 151-159. 